\title{
ACC/AHA/SCAI 2005 Guideline Update for Percutaneous Coronary Intervention-Summary Article
}

\section{A Report of the American College of Cardiology/American Heart Association Task Force on Practice Guidelines (ACC/AHA/SCAI Writing Committee to Update the 2001 Guidelines for Percutaneous Coronary Intervention)}

\author{
WRITING COMMITTEE MEMBERS \\ Sidney C. Smith, Jr, MD, FACC, FAHA, Chair; Ted E. Feldman, MD, FACC, FSCAI*; \\ John W. Hirshfeld, Jr, MD, FACC, FSCAI*; Alice K. Jacobs, MD, FACC, FAHA, FSCAI; \\ Morton J. Kern, MD, FACC, FAHA, FSCAI*; Spencer B. King, III, MD, MACC, FSCAI; \\ Douglass A. Morrison, MD, PhD, FACC, FSCAI*; William W. O’Neill, MD, FACC, FSCAI; \\ Hartzell V. Schaff, MD, FACC, FAHA; Patrick L. Whitlow, MD, FACC, FAHA; \\ David O. Williams, MD, FACC, FAHA, FSCAI

\section{TASK FORCE MEMBERS} \\ Elliott M. Antman, MD, FACC, FAHA, Chair; Sidney C. Smith, Jr, MD, FACC, FAHA, Vice-Chair; \\ Cynthia D. Adams, MSN, APRN-BC, FAHA; Jeffrey L. Anderson, MD, FACC, FAHA; \\ David P. Faxon, MD, FACC, FAHA + ; Valentin Fuster, MD, PhD, FACC, FAHA, FESC + ; \\ Jonathan L. Halperin, MD, FACC, FAHA; Loren F. Hiratzka, MD, FACC, FAHA $†$; \\ Sharon Ann Hunt, MD, FACC, FAHA; Alice K. Jacobs, MD, FACC, FAHA; \\ Rick Nishimura, MD, FACC, FAHA; Joseph P. Ornato, MD, FACC, FAHA; \\ Richard L. Page, MD, FACC, FAHA; Barbara Riegel, DNSc, RN, FAHA
}

$\mathrm{T}$ The American College of Cardiology/American Heart Association/Society for Cardiovascular Angiography and Interventions (ACC/AHA/SCAI) 2005 Guideline Update for Percutaneous Coronary Intervention (PCI) contains changes in the recommendations, along with supporting text. For the purpose of comparison, this summary contains a list of the updated recommendations (middle column) alongside a list of the 2001 recommendations (left column), with each set accompanied by a comment (right column) that provides the rationale for the changes, additions, or deletions (see Table 1). References

\footnotetext{
*Official SCAI representative.
}

$\dagger$ Former Task Force Member during this writing effort.

Acknowledgment: The ACC and AHA recognize Dr J. Ward Kennedy for his dedicated service on developing ACC/AHA guidelines for PTCA and PCI since their inception in 1986 and for his counsel and advice in the preparation of this guideline.

This document was approved by the American College of Cardiology Foundation Board of Trustees in September 2005, by the American Heart Association Science Advisory and Coordinating Committee in September 2005, and by the Society for Cardiovascular Angiography and Interventions in September 2005.

The ACC/AHA Task Force on Practice Guidelines makes every effort to avoid any actual or potential conflicts of interest that might arise as a result of an outside relationship or personal interest of a member of the writing panel. Specifically, all members of the writing panel are asked to provide disclosure statements of all such relationships that might be perceived as real or potential conflicts of interest. These statements are reviewed by the parent task force, reported orally to all members of the writing panel at the first meeting, and updated as changes occur. The relationship with industry information for writing committee members, as well as peer reviewers of the document, is located in an appendix of the full-text guideline, which is available on the ACC, AHA, and SCAI Web sites.

When citing this document, the American Heart Association requests that the following citation format be used: Smith SC Jr, Feldman TE, Hirshfeld JW Jr, Jacobs AK, Kern MJ, King SB III, Morrison DA, O’Neill WW, Schaff HV, Whitlow PL, Williams DO. ACC/AHA/SCAI 2005 guideline update for percutaneous coronary intervention-summary article: a report of the American College of Cardiology/American Heart Association Task Force on Practice Guidelines (ACC/AHA/SCAI Writing Committee to Update the 2001 Guidelines for Percutaneous Coronary Intervention). J Am Coll Cardiol 2006;47:216-35.

Copies: This document is available on the World Wide Web sites of the American College of Cardiology (www.acc.org), the American Heart Association (www.americanheart.org), and the Society for Cardiovascular Angiography and Interventions (www.scai.org). Single copies of this document are available by calling 1-800-253-4636 or writing the American College of Cardiology Foundation, Resource Center, at 9111 Old Georgetown Road, Bethesda, MD 20814-1699. Ask for reprint number 71-0346. To obtain a copy of the full text published in the January 3, 2006, issue of the Journal of the American College of Cardiology, the January 3, 2006, issue of Circulation, and the January 2006, issue of Catheterization and Cardiovascular Interventions, ask for reprint number 71-0347. To purchase bulk reprints (specify version and reprint number): Up to 999 copies, call 1-800-611-6083 US only) or fax 413-665-2671; 1000 or more copies, call 214-706-1789, fax 214-691-6342, or e-mail pubauth@heart.org.

Permissions: Multiple copies, modification, alteration, enhancement, and/or distribution of this document are not permitted without the express permission of the American College of Cardiology Foundation. Please direct requests to copyright_permissions@acc.org.

(C) 2006 by the American College of Cardiology Foundation and the American Heart Association, Inc.

(J Am Coll Cardiol 2006;47:216-35.) 
that support either the 2001 recommendations that have changed or the new or revised recommendations are cited in parentheses at the end of each recommendation or comment. A list of abbreviations is included in the Appendix. The reader is referred to the full-text guideline posted on the World Wide Web sites of the ACC, the AHA, and the SCAI for a more detailed explanation of the changes discussed here. Please note that we have changed the table of contents headings in the 2001 ACC/AHA Guidelines for Percutaneous Coronary Intervention from roman numerals to unique identifying numbers.

In preparing this update, the committee was guided by the following principles:

1. Changes in recommendations and levels of evidence were made because of the availability of data from new randomized trials, the accumulation of new clinical evidence, and/or the development of clinical consensus.

2. The committee is cognizant of the healthcare, logistic, and financial implications of recent trials and factored in these considerations in arriving at the class level of certain recommendations.

3. All recommendations in the PCI guideline update have been written in full sentences that express a complete thought, such that a recommendation, even if separated and presented apart from the rest of the document, will still convey the full intent of the recommendation.

4. The committee wishes to re-emphasize that the recommendations in the guideline apply to most patients but may require modification by existing situations that only the primary treating healthcare provider can evaluate properly.

5. The committee endeavored to maintain the consistency of recommendations in this and other previously pub- lished guidelines, primarily the ACC/AHA Guidelines for the Management of Patients With ST-Elevation Myocardial Infarction and the ACC/AHA 2002 Guideline Update for the Management of Patients With Non-ST-Elevation Myocardial Infarction.

The classification of recommendations and levels of evidence are expressed in the ACC/AHA format as follows:

\section{Classification of Recommendations}

Class I: Conditions for which there is evidence for and/or general agreement that a given procedure or treatment is beneficial, useful, and effective.

Class II: Conditions for which there is conflicting evidence and/or a divergence of opinion about the usefulness/efficacy of a procedure or treatment.

IIa: Weight of evidence/opinion is in favor of usefulness/efficacy.

IIb: Usefulness/efficacy is less well established by evidence/opinion.

Class III: Conditions for which there is evidence and/or general agreement that the procedure/treatment is not useful/ effective and in some cases may be harmful.

\section{Level of Evidence}

Level of Evidence A: Data derived from multiple randomized clinical trials or meta-analyses.

Level of Evidence B: Data derived from a single randomized trial or nonrandomized studies.

Level of Evidence C: Only consensus opinion of experts, case studies, or standard-of-care. 


\begin{tabular}{llc}
\hline 2001 Recommendation & 2005 New or Revised Recommendation & Comments \\
\hline 3. Outcomes & & \\
3.2 Acute Outcome: Procedural Complications &
\end{tabular}

\subsection{Acute Outcome: Procedural Complications}

Class I Class I

None

All patients who have signs or symptoms suggestive of MI during or after $\mathrm{PCl}$ and those with complicated procedures should have CK-MB and troponin I or T measured after the procedure. (Level of Evidence: $B$ )

Class Ila

None

\section{Class Ila}

Routine measurement of cardiac biomarkers (CK-MB and/or troponin I or $\mathrm{T}$ ) in all patients undergoing $\mathrm{PCl}$ is reasonable 8 to 12 hours after the procedure. (Level of Evidence: C)
This recommendation appeared in the text of the 2001 revision for CK-MB only. Troponin I or T measurement has been added, and it is now listed as a class I, level of evidence $B$ recommendation (1-10).

Routine measurement of CK-MB or troponin I or T is added as a new class lla, level of evidence $C$ recommendation. The committee did not think that evidence regarding the clinical utility of routine measurement of biomarkers in all patients was strong enough to warrant a class I recommendation.

4. Institutional and Operator Competency

4.1 Quality Assurance

Class I Class I

None
1. An institution that performs $\mathrm{PCl}$ should establish an ongoing mechanism for valid peer review of its quality and outcomes. Review should be conducted both at the level of the entire program and at the level of the individual practitioner. Quality-assessment reviews should take risk adjustment, statistical power, and national benchmark statistics into consideration. Quality-assessment reviews should include both tabulation of adverse event rates for comparison with benchmark values and case review of complicated procedures and some uncomplicated procedures. (Level of Evidence: $\mathrm{C}$ )

2. An institution that performs $\mathrm{PCl}$ should participate in a recognized $\mathrm{PCl}$ data registry for the purpose of benchmarking its outcomes against current national norms. (Level of Evidence: C)
Quality assurance is an important responsibility for all institutions in which $\mathrm{PCl}$ is performed. Institutions must monitor the $\mathrm{PCl}$ program with respect to process, appropriateness, and outcomes and correct any circumstances in which quality falls below accepted norms. The quality assessment should be conducted at the level of both the entire program and the individual practitioner.

Participation in a recognized $\mathrm{PCl}$ registry for benchmarking outcomes against current national norms is an important part of the quality-improvement process. The ACC-National Cardiovascular Data Registry ${ }^{\circledR}$ or other databases may serve as a valuable resource in this regard.

\subsection{Operator and Institutional Volume}

\section{Class I}

$\mathrm{PCl}$ done by operators with acceptable volume (greater than or equal to 75 ) at high-volume centers (greater than 400). (Level of Evidence: $B$ )

\section{Class Ila}

1. PCl done by operators with acceptable volume (75 or more) at low-volume centers (200-400). (Level of Evidence: C)

\section{Class I}

1. Elective PCl should be performed by operators with acceptable annual volume (at least 75 procedures) at high-volume centers (more than 400 procedures) with on-site cardiac surgery. (Level of Evidence: B)

2. Elective PCI should be performed by operators and institutions whose historical and current risk-adjusted outcomes statistics are comparable to those reported in contemporary national data registries. (Level of Evidence: $C$ )

3. Primary PCI for STEMI should be performed by experienced operators who perform more than 75 elective $\mathrm{PCl}$ procedures per year and, ideally, at least $11 \mathrm{PCl}$ procedures for STEMI per year. Ideally, these procedures should be performed in institutions that perform more than 400 elective PCls per year and more than 36 primary $\mathrm{PCl}$ procedures for STEMI per year. (Level of Evidence: $B$ )

\section{Class Ila}

1. It is reasonable that operators with acceptable volume (at least $75 \mathrm{PCl}$ procedures per year) perform $\mathrm{PCl}$ at low-volume centers (200 to $400 \mathrm{PCl}$ procedures per year) with on-site cardiac surgery. (Level of Evidence: B)
Wording has been added to clarify this statement and emphasize that it relates to elective $\mathrm{PCl}$ performed at centers with on-site cardiac surgery.

This recommendation was added to emphasize that historical and current risk-adjusted outcomes for operators and institutions are an essential part of the quality-improvement process.

This recommendation is expanded based on data from the New York State registry indicating that physicians performing more than 10 primary $\mathrm{PCl}$ procedures per year have lower mortality rates (11-13).

Wording has been changed to comply with current recommended phrasing for class lla recommendation. The fact that this recommendation applies to centers with on-site cardiac surgery is emphasized. Level of evidence has been changed to B based on accumulated published evidence (14). 
2001 Recommendation

2. PCl done by low-volume operators (fewer than 75) at high-volume centers (more than 400). Note: Ideally operators with an annual procedure volume less than 75 should only work at institutions with an activity level of more than 600 procedures/year.*

(Level of Evidence: $\mathrm{C}$ )

${ }^{*}$ Operators who perform fewer than 75 procedures per year should develop a defined mentoring relationship with a highly experienced operator who has an annual procedural volume of at least 150 procedures per year.

\section{Class Ilb}

None

\section{Class III}

$\mathrm{PCl}$ done by low-volume operators (fewer than 75) at low-volume centers (200-400). Note: An institution with a volume of fewer than 200 procedures/year, unless in a region that is underserved because of geography, should carefully consider whether it should continue to offer service. * (Level of Evidence: $\mathrm{C}$ )

*Operators who perform fewer than 75 procedures per year should develop a defined mentoring relationship with a highly experienced operator who has an annual procedural volume of at least 150 procedures per year.

\section{New or Revised Recommendation}

2. It is reasonable that low-volume operators (fewer than 75 $\mathrm{PCl}$ procedures per year) perform $\mathrm{PCl}$ at high-volume centers (more than $400 \mathrm{PCl}$ procedures per year) with on-site cardiac surgery. Ideally, operators with an annual procedure volume less than 75 should only work at institutions with an activity level of more than 600 procedures per year. Operators who perform fewer than 75 procedures per year should develop a defined mentoring relationship with a highly experienced operator who has an annual procedural volume of at least 150 procedures per year. (Level of Evidence: $B$ )

\section{Class Ilb}

The benefit of primary PCI for STEMI patients eligible for fibrinolysis when performed by an operator who performs fewer than 75 procedures per year (or fewer than $11 \mathrm{PCls}$ for STEMI per year) is not well established. (Level of Evidence: C)

\section{Class III}

It is not recommended that elective $\mathrm{PCl}$ be performed by low-volume operators (fewer than 75 procedures per year) at low-volume centers (200 to 400) with or without on-site cardiac surgery. An institution with a volume of fewer than 200 procedures per year, unless in a region that is underserved because of geography, should carefully consider whether it should continue to offer this service. (Level of Evidence: B)
This recommendation has been added to address the issue of low-volume operators performing primary $\mathrm{PCl}$. It reflects the relative lack of evidence supporting a benefit of primary $\mathrm{PCl}$ for low-volume operators.

Wording has been changed to reflect current preferred phrasing. Level of evidence changed to $B$ on the basis of published data indicating poorer outcomes at low-volume centers (15).

\subsection{Role of On-Site Cardiac Surgical Back-up}

\section{Class I Class I}

1. Patients undergoing elective $\mathrm{PCl}$ in facilities with on-site cardiac surgery. (Level of Evidence: B)

2. Patients undergoing primary $\mathrm{PCl}$ in facilities with on-site cardiac surgery. (Level of Evidence: B)

\section{Class III}

Patients undergoing elective $\mathrm{PCl}$ in facilities without on-site cardiac surgery. (Level of Evidence: C)

\section{Class III}

Elective PCl should not be performed at institutions that do not provide on-site cardiac surgery. (Level of Evidence: $C$ ) *Several centers have reported satisfactory results based on careful case selection with well-defined arrangements for immediate transfer to a surgical program (18-28). A small, but real fraction of patients undergoing elective $\mathrm{PCl}$ will experience a life-threatening complication that could be managed with the immediate on-site availability of cardiac surgical support but cannot be managed effectively by urgent transfer. Wennberg et al. found higher mortality in the Medicare database for patients undergoing elective $\mathrm{PCl}$ in institutions without onsite cardiac surgery (29). These recommendations may be subject to revision as clinical data and experience increase.
Wording has been changed to comply with current recommended phasing. Level of evidence has been changed to $B$ based on accumulated published evidence (15).
Phrasing has been changed to reflect current terminology and volume criteria; otherwise, no significant changes.

Phrasing has been changed to reflect current terminology and to be consistent with the ACC/AHA Guidelines for the Management of Patients With ST-Elevation Myocardial Infarction.

Phrasing has been changed to reflect current terminology. As with many dynamic areas in interventional cardiology, these recommendations may be subject to revision as clinical data and experience increase. 


\begin{tabular}{l}
\hline 2001 Recommendation \\
\hline Section 4.4 Primary PCI for STEMI \\
\hline Class Ilb \\
Patients undergoing primary PCI in \\
facilities without on-site cardiac surgery, \\
but with a proven plan for rapid access \\
(within 1 h) to a cardiac surgery \\
operating room in a nearby facility with \\
appropriate hemodynamic support \\
capability for transfer. The procedure \\
should be limited to patients with \\
ST-segment elevation MI or new LBBB \\
on ECG, and done in a timely fashion \\
(balloon inflation within 90 plus or minus \\
30 min of admission) by persons skilled \\
in the procedure (at least 75 PCls/year) \\
and only at facilities performing a \\
minimum of 36 primary PCI procedures \\
per year. (Level of Evidence: B)
\end{tabular}

\section{Class III}

Patients undergoing primary $\mathrm{PCl}$ in facilities without on-site cardiac surgery and without a proven plan for rapid access (within $1 \mathrm{~h}$ ) to a cardiac surgery operating room in a nearby facility with appropriate hemodynamic support capability for transfer or when performed by lower-skilled operators (fewer than 75 PCls per year) in a facility performing fewer than 36 primary $\mathrm{PCl}$ procedures per year. (Level of Evidence: $C$ )
2005 New or Revised Recommendation

Comments

4.5 Elective PCI Without On-Site Surgery

\section{Class III Class III}

Patients undergoing elective $\mathrm{PCl}$ in facilities without on-site cardiac surgery. (Level of Evidence: C)

\section{Class Ilb}

Primary PCl for patients with STEMI might be considered in hospitals without on-site cardiac surgery, provided that appropriate planning for program development has been accomplished, including appropriately experienced physician operators (more than 75 total PCls and, ideally, at least 11 primary PCls per year for STEMI), an experienced catheterization team on a 24 hours per day, 7 days per week call schedule, and a well-equipped catheterization laboratory with digital imaging equipment, a full array of interventional equipment, and intra-aortic balloon pump capability, and provided that there is a proven plan for rapid transport to a cardiac surgery operating room in a nearby hospital with appropriate hemodynamic support capability for transfer. The procedure should be limited to patients with STEMI or Ml with new or presumably new LBBB on ECG and should be performed in a timely fashion (goal of balloon inflation within 90 minutes of presentation) by persons skilled in the procedure (at least 75 PCls per year) and at hospitals that perform a minimum of 36 primary PCl procedures per year. (Level of Evidence: B)

\section{Class III}

Primary PCl should not be performed in hospitals without on-site cardiac surgery and without a proven plan for rapid transport to a cardiac surgery operating room in a nearby hospital or without appropriate hemodynamic support capability for transfer. (Level of Evidence: $\mathrm{C}$ )
Phrasing has been changed to reflect current terminology. Recommendations have been added that 1) physicians perform at least 11 primary $\mathrm{PCls}$ per year for STEMI, 2) a 24 hours per day, 7 days per week call schedule be maintained, and 3) the catheterization laboratory be well equipped with digital imaging equipment, a full array of interventional equipment, and intra-aortic balloon pump capability. The intent is to ensure optimal experience availability and capability to perform primary $\mathrm{PCI}$ in patients with STEMI $(16,17)$.

Phrasing has been changed to reflect current terminology and to place emphasis on need for inter-institutional planning and support.
Elective PCI should not be performed at institutions that do not provide on-site cardiac surgery. (Level of Evidence: $C$ ) *Several centers have reported satisfactory results based on careful case selection with well-defined arrangements for immediate transfer to a surgical program (18-28). A small, but real fraction of patients undergoing elective $\mathrm{PCl}$ will experience a life-threatening complication that could be managed with the immediate on-site availability of cardiac surgical support but cannot be managed effectively by urgent transfer. Wennberg et al. found higher mortality in the Medicare database for patients undergoing elective $\mathrm{PCl}$ in institutions without onsite cardiac surgery (29). These recommendations may be subject to revision as clinical data and experience increase.

\subsection{Patients With Asymptomatic Ischemia or Canadian Cardiovascular Society (CCS) Class I or II Angina}

\section{Class I}

Patients who do not have treated diabetes with asymptomatic ischemia or mild angina with 1 or more significant lesions in 1 or 2 coronary arteries suitable for PCl with a high likelihood of success and a low risk of morbidity and mortality. The vessels to be dilated must subtend a large area of viable myocardium. (Level of Evidence: B)

\section{Class Ila}

1. The same clinical and anatomic requirements for Class I, except the myocardial area at risk is of moderate size or the patient has treated diabetes. (Level of Evidence: B)

\section{Class Ila}

1. $\mathrm{PCl}$ is reasonable in patients with asymptomatic ischemia or CCS class I or II angina and with 1 or more significant lesions in 1 or 2 coronary arteries suitable for PCl with a high likelihood of success and a low risk of morbidity and mortality. The vessels to be dilated must subtend a moderate to large area of viable myocardium or be associated with a moderate to severe degree of ischemia on noninvasive testing. (Level of Evidence: B)
Repeated from previous section for consistency. Phrasing has been changed to reflect current terminology.
Phrasing has been changed to reflect current terminology. This recommendation and all of those that follow in Section 5 have been reworded to be consistent with the CCS classification system of angina. This recommendation has been changed to class lla to reflect the published data and Writing Committee consensus that not all patients in this clinical category must have $\mathrm{PCl}$ performed $(30,31)$.
This recommendation has been merged with other class lla recommendations of this section, and the phrasing has been changed to reflect current terminology. 
2005 New or Revised Recommendation

2. $\mathrm{PCl}$ is reasonable for patients with asymptomatic ischemia or CCS class I or II angina, and recurrent stenosis after PCl with a large area of viable myocardium or high-risk criteria on noninvasive testing. (Level of Evidence: $\mathrm{C}$ )

3. Use of $\mathrm{PCl}$ is reasonable in patients with asymptomatic ischemia or CCS class I or II angina with significant left main CAD (greater than $50 \%$ diameter stenosis) who are candidates for revascularization but are not eligible for CABG. (Level of Evidence: $B$ )

\section{Class Illb}

Patients with asymptomatic ischemia or mild angina with greater than or equal to 3 coronary arteries suitable for $\mathrm{PCl}$ with a high likelihood of success and a low risk of morbidity and mortality. The vessels to be dilated must subtend at least a moderate area of viable myocardium. In the physician's judgment, there should be evidence of myocardial ischemia by ECG exercise testing, stress nuclear imaging, stress echocardiography or ambulatory ECG monitoring or intracoronary physiologic measurements. (Level of Evidence: B)

\section{Class III}

Patients with asymptomatic ischemia or mild angina who do not meet the criteria as listed under Class I or Class II and who have:

a. Only a small area of viable

myocardium at risk

b. No objective evidence of ischemia

c. Lesions that have a low likelihood

of successful dilatation

d. Mild symptoms that are unlikely

to be due to myocardial ischemia

e. Factors associated with increased

risk of morbidity or mortality

f. Left main disease

g. Insignificant disease less than

50\% (Level of Evidence: C)

\section{Class IIb}

1. The effectiveness of $\mathrm{PCl}$ for patients with asymptomatic ischemia or CCS class I or II angina who have 2- or 3-vessel disease with significant proximal LAD CAD who are otherwise eligible for CABG with 1 arterial conduit and who have treated diabetes or abnormal LV function is not well established. (Level of Evidence: $B$ )

2. PCl might be considered for patients with asymptomatic ischemia or CCS class I or II angina with nonproximal LAD CAD that subtends a moderate area of viable myocardium and demonstrates ischemia on noninvasive testing. (Level of Evidence: C)

\section{Class III}

$\mathrm{PCl}$ is not recommended in patients with asymptomatic ischemia or CCS class I or II angina who do not meet the criteria as listed under the class II recommendations or who have 1 or more of the following:

a. Only a small area of viable myocardium at risk (Level of Evidence: $\mathrm{C}$ )

b. No objective evidence of ischemia (Level of Evidence: $C$ )

c. Lesions that have a low likelihood of successful dilatation (Level of Evidence: C)

d. Mild symptoms that are unlikely to be due to myocardial ischemia (Level of Evidence: C)

e. Factors associated with increased risk of morbidity or mortality (Level of Evidence: $C$ )

$f$. Left main disease and eligibility for CABG (Level of

Evidence: C)

g. Insignificant disease (less than $50 \%$ coronary stenosis)

(Level of Evidence: C)

\subsection{Patients With CCS Class III Angina}

\section{Class I}

Patients with 1 or more significant lesions in 1 or more coronary arteries suitable for $\mathrm{PCl}$ with a high likelihood of success and low risk of morbidity or mortality. The vessel(s) to be dilated must subtend a moderate or large area of viable myocardium and have high risk. (Level of Evidence: B)

\section{Class Ila}

1. It is reasonable that $\mathrm{PCl}$ be performed in patients with CCS class III angina and single-vessel or multivessel CAD who are undergoing medical therapy and who have 1 or more significant lesions in 1 or more coronary arteries suitable for $\mathrm{PCl}$ with a high likelihood of success and low risk of morbidity or mortality. (Level of Evidence: B)
Phrasing has been changed to reflect current terminology. Among patients who are eligible, CABG with 1 arterial conduit is generally preferred for treatment of multivessel disease with significant proximal LAD obstruction in patients with treated diabetes and/or abnormal LV function (36).

Phrasing has been changed to reflect current terminology. PCl might be considered in this clinical setting.

Phrasing has been changed to reflect current terminology. Recommendation has been reworded to be consistent with CCS classification system for angina. Level of evidence has been added for each subgroup.
Phrasing has been changed to reflect current terminology. Recommendation has been reworded to be consistent with CCS classification system for angina. The recommendation class has been changed to lla to reflect published data and Writing Committee consensus. Criteria regarding viable and high-risk myocardium have been deleted from this recommendation $(30,31)$. 


\begin{tabular}{l}
\hline 2001 Recommendation \\
\hline Class Ila \\
Patients with focal saphenous vein \\
graft lesions or multiple stenoses \\
who are poor candidates for \\
reoperative surgery. (Level of \\
Evidence: $C$ )
\end{tabular}

\section{Class Ilb}

Patient has 1 or more lesions to be dilated with reduced likelihood of success or the vessel(s) subtend a less than moderate area of viable myocardium. Patients with 2- or 3-vessel disease, with significant proximal $L A D C A D$ and treated diabetes or abnormal LV function. (Level of Evidence: B)

\section{Class III}

Patient has no evidence of myocardial injury or ischemia on objective testing and has not had a trial of medical therapy, or has

a. Only a small area of myocardium at risk

b. All lesions or the culprit lesion

to be dilated with morphology with a low likelihood of success

c. A high risk of procedure-related morbidity or mortality. (Level of Evidence: C)

2. Patients with insignificant coronary stenosis (e.g., less than $50 \%$ diameter). (Level of Evidence: C)

3. Patients with significant left main CAD who are candidates for CABG. (Level of Evidence: $B$ )

2005 New or Revised Recommendation

Comments

2. It is reasonable that PCI be performed in patients with CCS class III angina with single-vessel or multivessel CAD who are undergoing medical therapy with focal saphenous vein graft lesions or multiple stenoses who are poor candidates for reoperative surgery. (Level of Evidence: $C$ )

3. Use of $\mathrm{PCl}$ is reasonable in patients with CCS class III angina with significant left main CAD (greater than $50 \%$ diameter stenosis) who are candidates for revascularization but are not eligible for CABG. (Level of Evidence: B)

\section{Class IIb}

1. PCI may be considered in patients with CCS class III angina with single-vessel or multivessel CAD who are undergoing medical therapy and who have 1 or more lesions to be dilated with a reduced likelihood of success. (Level of Evidence: $B$ )

2. PCI may be considered in patients with CCS class III angina and no evidence of ischemia on noninvasive testing or who are undergoing medical therapy and have 2- or 3-vessel CAD with significant proximal $L A D C A D$ and treated diabetes or abnormal LV function. (Level of Evidence: $B$ )

\section{Class III}

$\mathrm{PCl}$ is not recommended for patients with CCS class III angina with single-vessel or multivessel CAD, no evidence of myocardial injury or ischemia on objective testing, and no trial of medical therapy, or who have 1 of the following:

a. Only a small area of myocardium at risk (Level of

Evidence: C)

b. All lesions or the culprit lesion to be dilated with morphology that conveys a low likelihood of success (Level of Evidence: C)

c. A high risk of procedure-related morbidity or mortality (Level of Evidence: C)

d. Insignificant disease (less than $50 \%$ coronary stenosis) (Level of Evidence: $C$ )

e. Significant left main CAD and candidacy for CABG (Level of Evidence: C)
Phrasing has been changed to reflect current terminology.

This recommendation for $\mathrm{PCl}$ among patients with significant left main disease who are not eligible for CABG has been added to reflect the favorable results noted by several trials with $\mathrm{PCl}$ (32-35).

Phrasing has been changed to reflect current terminology. The 2001 recommendation has been split into 2 separate recommendations.

Phrasing has been changed to reflect current terminology. The use of noninvasive testing to evaluate for evidence of ischemia has been added.

Phrasing has been changed to reflect current terminology. Class III recommendations \#2 and \#3 from the 2001 guidelines have been merged into this recommendation.
An early invasive $\mathrm{PCl}$ strategy is indicated for patients with UA/NSTEMI who have no serious comorbidity and who have coronary lesions amenable to $\mathrm{PCl}$. Patients must have any of the following high-risk features:

a. Recurrent ischemia despite intensive anti-ischemic

therapy (Level of Evidence: A)

b. Elevated troponin level (Level of Evidence: A)

c. New ST-segment depression (Level of Evidence: A)

d. CHF symptoms or new or worsening MR (Level of

Evidence: A)

e. Depressed LV systolic function (Level of Evidence: A)

f. Hemodynamic instability (Level of Evidence: A)

g. Sustained ventricular tachycardia (Level of Evidence: $A$ )

h. PCl within 6 months (Level of Evidence: A)

i. Prior CABG (Level of Evidence: A)
Added to maintain consistency with the ACC/AHA 2002 Guideline Update for the Management of Patients With Unstable Angina and Non-ST-Segment Myocardial Infarction (37). 


\section{Recommendation}

\section{Class Ila}

1. Patients with focal saphenous vein graft lesions or multiple stenoses who are poor candidates for reoperative surgery. (Level of Evidence: $\mathrm{C}$

2. All patients after a non-Q-wave

MI. (Level of Evidence: C)

\section{Class III}

1. Patient has no evidence of myocardial injury or ischemia on objective testing and has not had a trial of medical therapy, or has

a. Only a small area of myocardium at risk

b. All lesions or the culprit lesion to be dilated with morphology with a low likelihood of success

c. A high risk of procedure-related morbidity or mortality. (Level of Evidence: C)

2. Patients with insignificant coronary stenosis (e.g., less than $50 \%$ diameter). (Level of Evidence: C)

3. Patients with significant left main CAD who are candidates for CABG.

(Level of Evidence: B)
2005 New or Revised Recommendation

Comments

Class Ila

1. It is reasonable that $\mathrm{PCl}$ be performed in patients with UA/NSTEMI and single-vessel or multivessel CAD who are undergoing medical therapy with focal saphenous vein graft lesions or multiple stenoses who are poor candidates for reoperative surgery. (Level of Evidence: $C$ )

2. In the absence of high-risk features associated with UA/NSTEMI, it is reasonable to perform PCI in patients with amenable lesions and no contraindication for $\mathrm{PCl}$ with either an early invasive or early conservative strategy. See full-text guidelines. (Level of Evidence: B)

3. Use of $\mathrm{PCl}$ is reasonable in patients with UA/NSTEMI with significant left main CAD (greater than 50\% diameter stenosis) who are candidates for revascularization but are not eligible for CABG. (Level of Evidence: B)

\section{Class Ilb}

1. In the absence of high-risk features associated with UA/NSTEMI, PCl may be considered in patients with single-vessel or multivessel CAD who are undergoing medical therapy and who have 1 or more lesions to be dilated with reduced likelihood of success. (Level of Evidence: $B$ )

2. $\mathrm{PCl}$ may be considered in patients with UA/NSTEMI who are undergoing medical therapy who have 2- or 3-vessel disease, significant proximal LAD CAD, and treated diabetes or abnormal LV function. (Level of Evidence: B)

\section{Class III}

1. In the absence of high-risk features associated with UA/NSTEMI, $\mathrm{PCl}$ is not recommended for patients with UA/NSTEMI with single-vessel or multivessel CAD and no trial of medical therapy, or who have 1 or more of the following

a. Only a small area of myocardium at risk (Level of

Evidence: C)

b. All lesions or the culprit lesion to be dilated with morphology that conveys a low likelihood of success (Level of Evidence: $C$ )

c. A high risk of procedure-related morbidity or mortality

(Level of Evidence: C)

d. Insignificant disease (less than $50 \%$ coronary stenosis)

(Level of Evidence: $C$ )

e. Significant left main CAD and candidacy for CABG (Level of Evidence: B)
Phrasing has been changed to reflect current terminology.

Added in accordance with growing evidence regarding $\mathrm{PCl}$ for patients with UA/NSTEMI $(30,37-39)$.

Added in accordance with growing evidence regarding $\mathrm{PCl}$ for patients with UA/NSTEMI (32-35, 40-43).

Phrasing has been changed to reflect current terminology. Original recommendation replaced by 2 separate recommendations as noted here and in the following recommendations.

See above.

This recommendation was removed because it is now covered by the revised recommendations from the ACC/AHA 2002 Guideline Update for the Management of Patients With Unstable Angina and Non-ST-Segment Myocardial Infarction.

Phrasing has been changed to reflect current terminology and level of evidence for each subgroup. Class III recommendations \#2 and \#3 from the 2001 guidelines have been merged into this recommendation.

See above.

See above.

\subsection{Patients With STEMI}

The phrasing has been changed to reflect current terminology as needed for all recommendations in this section and to be consistent with the ACC/AHA Guidelines for the Management of Patients With ST-Elevation Myocardial Infarction. 


\begin{tabular}{|c|c|}
\hline 2001 Recommendation & 2005 New or Revised Recommendation \\
\hline \multicolumn{2}{|c|}{ 5.4.1. General and Specific Considerations } \\
\hline Class I & Class I \\
\hline $\begin{array}{l}\text { 1. As an alternative to thrombolytic } \\
\text { therapy in patients with AMI and } \\
\text { ST-segment elevation or new or } \\
\text { presumed new left bundle-branch } \\
\text { block who can undergo angioplasty } \\
\text { of the infarct artery less than or } \\
\text { equal to } 12 \mathrm{~h} \text { from the onset of } \\
\text { ischemic symptoms or more than } 12 \\
\mathrm{~h} \text { if symptoms persist, if performed } \\
\text { in a timely fashion* by individuals } \\
\text { skilled in the procedure† and } \\
\text { supported by experienced personnel } \\
\text { in an appropriate laboratory } \\
\text { environment.‡ (Level of Evidence: A) } \\
\text { *Performance standard: balloon } \\
\text { inflation within } 90 \text { plus or minus } 30\end{array}$ & $\begin{array}{l}\text { General considerations: } \\
\text { 1. If immediately available, primary PCI should be performed in } \\
\text { patients with STEMI (including true posterior MI) or MI with } \\
\text { new or presumably new LBBB who can undergo PCl of the } \\
\text { infarct artery within } 12 \text { hours of symptom onset, if performed } \\
\text { in a timely fashion (balloon inflation goal within } 90 \text { minutes of } \\
\text { presentation) by persons skilled in the procedure (individuals } \\
\text { who perform more than } 75 \mathrm{PCl} \text { procedures per year, ideally at } \\
\text { least } 11 \text { PCls per year for STEMI). The procedure should be } \\
\text { supported by experienced personnel in an appropriate } \\
\text { laboratory environment (one that performs more than } 200 \mathrm{PCl} \\
\text { procedures per year, of which at least } 36 \text { are primary PCI for } \\
\text { STEMI, and that has cardiac surgery capability). (Level of } \\
\text { Evidence: A) Primary PCl should be performed as quickly as } \\
\text { possible, with a goal of a medical contact-to-balloon or } \\
\text { door-to-balloon time within } 90 \text { minutes. (Level of Evidence: B) }\end{array}$ \\
\hline
\end{tabular}

min of hospital admission.

†Individuals who perform 75 or more $\mathrm{PCl}$ procedures per year.

$\ddagger$ Centers that perform more than $200 \mathrm{PCI}$ procedures per year and have cardiac surgical capability.

2. In patients who are within $36 \mathrm{~h}$ of an acute ST elevation/Q-wave or new left bundle-branch block Ml who develop cardiogenic shock, are less than 75 years of age, and revascularization can be performed within $18 \mathrm{~h}$ of the onset of shock by individuals skilled in the procedure $†$ and supported by experienced personnel in an appropriate laboratory environment.ł (Level of Evidence: A) †Individuals who perform 75 or more $\mathrm{PCl}$ procedures per year.

$\neq$ Centers that perform more than 200 $\mathrm{PCl}$ procedures per year and have cardiac surgical capability $(193,194)$.
Specific considerations:

2. Primary PCl should be performed for patients less than 75 years old with ST elevation or presumably new LBBB who develop shock within 36 hours of $\mathrm{Ml}$ and are suitable for revascularization that can be performed within 18 hours of shock, unless further support is futile because of the patient's wishes or contraindications/unsuitability for further invasive care. (Level of Evidence: A)

3. Primary PCl should be performed in patients with severe HF and/or pulmonary edema (Killip class 3 ) and onset of symptoms within 12 hours. The medical contact-to-balloon or door-to-balloon time should be as short as possible (i.e., goal within 90 minutes). (Level of Evidence: B)

\section{Class Ila}

1. Primary $\mathrm{PCl}$ is reasonable for selected patients 75 years or older with ST elevation or LBBB or who develop shock within 36 hours of MI and are suitable for revascularization that can be performed within 18 hours of shock. Patients with good prior functional status who are suitable for revascularization and agree to invasive care may be selected for such an invasive strategy. (Level of Evidence: $B$ )

2. It is reasonable to perform primary $\mathrm{PCl}$ for patients with onset of symptoms within the prior 12 to 24 hours and 1 or more of the following:
a. Severe HF (Level of Evidence: C)
b. Hemodynamic or electrical instability (Level of Evidence: C)
c. Evidence of persistent ischemia (Level of Evidence: $\mathrm{C}$ )

Phrasing has been changed to reflect current terminology to be consistent with the ACC/AHA Guidelines for the Management of Patients With ST-Elevation Myocardial Infarction. This revised recommendation reflects the evidence from several trials and a meta-analysis of 23 trials comparing PCl with fibrinolysis that confirm the advantage of PCl. The conditions under which $\mathrm{PCl}$ must be performed to optimize this advantage are included in the recommendation (11-13,44-47).

Phrasing has been changed to reflect current terminology. The changes from the ACC/AHA Guidelines for the Management of Patients With ST-Elevation Myocardial Infarction have been included in this recommendation (48-53).

The changes from the ACC/AHA Guidelines for the Management of Patients With ST-Elevation Myocardial Infarction are included in this new recommendation, which emphasizes the benefits of $\mathrm{PCl}$ for patients with severe CHF and onset of symptoms within 12 hours (54-56).

This recommendation, which addresses the benefit of $\mathrm{PCl}$ in patients at least 75 years of age with shock, is included from the ACC/AHA Guidelines for the Management of Patients With ST-Elevation Myocardial Infarction with phrasing to reflect current terminology (48-53).

This new recommendation provides guidance for use of primary $\mathrm{PCl}$ within 12 to 24 hours of symptom onset in certain patient subsets. Phrasing has been changed to reflect current terminology and to be consistent with the ACC/AHA Guidelines for the Management of Patients With ST-Elevation Myocardial Infarction. 


\begin{tabular}{|c|c|c|}
\hline 2001 Recommendation & 2005 New or Revised Recommendation & Comments \\
\hline Class III & Class III & \\
\hline $\begin{array}{l}\text { 1. Elective } \mathrm{PCl} \text { of a } \\
\text { non-infarct-related artery at the time } \\
\text { of acute Ml. (Level of Evidence: } \mathrm{C} \text { ) }\end{array}$ & $\begin{array}{l}\text { 1. Elective PCl should not be performed in a } \\
\text { non-infarct-related artery at the time of primary } \mathrm{PCl} \text { of the } \\
\text { infarct-related artery in patients without hemodynamic } \\
\text { compromise. (Level of Evidence: } \mathrm{C} \text { ) }\end{array}$ & $\begin{array}{l}\text { Phrasing has been changed to reflect current } \\
\text { terminology. Important phrasing has been added to } \\
\text { address the issue of PCl of the non-infarct-related } \\
\text { coronary artery at the time of primary PCl. }\end{array}$ \\
\hline $\begin{array}{l}\text { 2. In patients with acute Ml who: } \\
\text { a. have received fibrinolytic } \\
\text { therapy within } 12 \mathrm{~h} \text { and have no } \\
\text { symptoms of myocardial ischemia } \\
\text { b. are eligible for thrombolytic therapy } \\
\text { and are undergoing primary } \\
\text { angioplasty by an inexperienced } \\
\text { operator (Individual who performs } \\
\text { fewer than } 75 \mathrm{PCl} \text { procedures per } \\
\text { year) } \\
\text { c. are beyond } 12 \mathrm{~h} \text { after onset of } \\
\text { symptoms and have no evidence of } \\
\text { myocardial ischemia. (Level of } \\
\text { Evidence: } \mathrm{C} \text { ) }\end{array}$ & $\begin{array}{l}\text { 2. Primary PCl should not be performed in asymptomatic } \\
\text { patients more than } 12 \text { hours after onset of STEMI who are } \\
\text { hemodynamically and electrically stable. (Level of Evidence: C) } \\
\text { Class Ilb } \\
\text { 1. The benefit of primary PCl for STEMI patients eligible for } \\
\text { fibrinolysis when performed by an operator who performs } \\
\text { fewer than } 75 \mathrm{PCl} \text { procedures per year (or fewer than } 11 \mathrm{PCls} \\
\text { for STEMI per year) is not well established. (Level of Evidence: } \\
\text { C) }\end{array}$ & $\begin{array}{l}\text { Phrasing has been changed to reflect current } \\
\text { terminology. Recommendation has been divided to } \\
\text { emphasize specific points. The class llb } \\
\text { recommendation was upgraded in the ACC/AHA } \\
\text { Guidelines for the Management of Patients With } \\
\text { ST-Elevation Myocardial Infarction and approved by the } \\
\text { PCI Writing Committee. }\end{array}$ \\
\hline
\end{tabular}

\subsubsection{PCI in Fibrinolytic-Ineligible Patients}

\section{Class Ila}

As a reperfusion strategy in candidates who have a contraindication to thrombolytic therapy. (Level of Evidence: C)

\section{Class I}

Primary $\mathrm{PCl}$ should be performed in fibrinolytic-ineligible patients who present with STEMI within 12 hours of symptom onset. (Level of Evidence: C)
Revised recommendation reflects the committee's opinion that primary PCl should be a class I recommendation for fibrinolytic-ineligible patients within 12 hours of symptom onset. Phrasing has been changed to reflect current terminology and to be consistent with the ACC/AHA Guidelines for the Management of Patients With ST-Elevation Myocardial Infarction.

New recommendation from the ACC/AHA Guidelines for the Management of Patients With ST-Elevation Myocardial Infarction that addresses conditions under which primary $\mathrm{PCl}$ is reasonable for fibrinolytic-ineligible patients with onset of symptoms within the prior 12 to 24 hours.
It is reasonable to perform primary $\mathrm{PCl}$ for fibrinolytic-ineligible patients with onset of symptoms within the prior 12 to 24 hours and 1 or more of the following:
a. Severe HF (Level of Evidence: $C$ )
b. Hemodynamic or electrical instability (Level of Evidence:
c)

c. Evidence of persistent ischemia (Level of Evidence: C)

\subsubsection{Facilitated PCI}

Class Ilb Class Ilb

None

Facilitated $\mathrm{PCl}$ might be performed as a reperfusion strategy in higher-risk patients when $\mathrm{PCl}$ is not immediately available and bleeding risk is low. (Level of Evidence: B)
New recommendation from the ACC/AHA Guidelines for the Management of Patients With ST-Elevation Myocardial Infarction addressing conditions for which facilitated PCI might be considered. Important randomized trials are under way, and more data are needed regarding outcomes resulting from this treatment strategy (57-63).

\subsubsection{PCI After Failed Fibrinolysis (Rescue PCI)}

Class I Class I

1. Rescue $\mathrm{PCl}$ should be performed in patients less than 75 years old with ST elevation or LBBB who develop shock within 36 hours of $\mathrm{Ml}$ and are suitable for revascularization that can be performed within 18 hours of shock, unless further support is futile because of the patient's wishes or contraindications/unsuitability for further invasive care. (Level of Evidence: $B$ )

2. Rescue $\mathrm{PCl}$ should be performed in patients with severe HF and/or pulmonary edema (Killip class 3 ) and onset of symptoms within 12 hours. (Level of Evidence: B)
See above $(49,51)$.

See above (54-56). 


\begin{tabular}{ll}
\hline 2001 Recommendation & 2005 New or Revised Recommendation \\
\hline Class Ila & Class Ila \\
None & 1. Rescue PCI is reasonable for selected patients 75 years or \\
& older with ST elevation or LBBB or who develop shock within \\
& 36 hours of Ml and are suitable for revascularization that can \\
be performed within 18 hours of shock. Patients with good \\
prior functional status who are suitable for revascularization \\
and agree to invasive care may be selected for such an \\
invasive strategy. (Level of Evidence: B) \\
2. It is reasonable to perform rescue PCl for patients with 1 or \\
more of the following: \\
a. Hemodynamic or electrical instability (Level of Evidence: \\
C) \\
b. Evidence of persistent ischemia. (Level of Evidence: $C$ )
\end{tabular}

Comments

\section{Class Ilb}

Recurrent angina without objective evidence of ischemia/infarction.

(Level of Evidence: C)

\section{Class III}

Routine PTCA within $48 \mathrm{~h}$ following failed thrombolysis. (Level of Evidence: B)

\section{Class III}

Rescue PCI in the absence of 1 or more of the above class I or lla indications is not recommended. (Level of Evidence: $\mathrm{C}$ )
See above (49).

Phrasing has been changed to reflect current terminology.

Deleted. Recurrent angina is not applicable to rescue angioplasty. Recurrent symptoms are discussed elsewhere.

Evidence obtained from studies of PTCA during the fibrinolytic era before the use of stents failed to show a benefit for reperfusion under these conditions. Current trials are under way to investigate the outcome of $\mathrm{PCl}$ with stent placement among patients with occluded arteries days after presentation with STEMI.

\subsubsection{PCI After Successful Fibrinolysis or for Patients Not Undergoing Primary Reperfusion}

\section{Class I Class I}

1. Objective evidence for recurrent infarction or ischemia (rescue PCl). (Level of Evidence: B)

2. Spontaneous or provocable myocardial ischemia during recovery from infarction. (Level of Evidence: C)

3. Persistent hemodynamic instability. (Level of Evidence: C)

\section{Class Ila}

Patients with LV ejection fraction less than or equal to 0.4 , CHF, or serious ventricular arrhythmias. (Level of Evidence: C)

\section{Class IIb}

1. Coronary angiography and angioplasty for an occluded infarct-related artery in an otherwise stable patient to revascularize that artery (open artery hypothesis). (Level of Evidence: C)

2. Angioplasty of the infarct-related artery stenosis within hours to days (48 h) following successful thrombolytic therapy in asymptomatic patients without clinical and/or inducible evidence of ischemia. (Level of Evidence: $B$ )
1. In patients whose anatomy is suitable, $\mathrm{PCl}$ should be performed when there is objective evidence of recurrent Ml. (Level of Evidence: C)

2. In patients whose anatomy is suitable, $\mathrm{PCl}$ should be performed for moderate or severe spontaneous or provocable myocardial ischemia during recovery from STEMI. (Level of Evidence: B)

3. In patients whose anatomy is suitable, $\mathrm{PCl}$ should be performed for cardiogenic shock or hemodynamic instability. See also Section 5.4.6 of the full-text guidelines. (Level of Evidence: B)

\section{Class Ila}

1. It is reasonable to perform routine $\mathrm{PCl}$ in patients with $\mathrm{LV}$ ejection fraction less than or equal to 0.40 , CHF, or serious ventricular arrhythmias. (Level of Evidence: $\mathrm{C}$ )
Phrasing has been changed to reflect current terminology. Revised to a level of evidence C.

Phrasing has been changed to reflect current terminology. Level of evidence revised on the basis of review by the Writing Committee (64).

Phrasing has been changed to reflect current terminology. Level of evidence was revised on the basis of review by the Writing Committee, and cardiogenic shock has been added (cardiogenic shock is discussed in Section 5.4.6 and is a class I, level of evidence A recommendation for patients younger than 75 years old and a class lla, level of evidence $B$ recommendation for those aged 75 years and older) (49).

Phrasing has been changed to reflect current terminology.

Recommendation deleted. Important trials are under way to provide evidence regarding outcomes associated with or resulting from this therapy.

This recommendation has been merged into the upgraded class $\mathrm{Ilb}$ recommendation for $\mathrm{PCl}$ after fibrinolytic therapy below. 


\section{Class Ila}

3. Clinical HF during the acute episode, but subsequent demonstration of preserved LV function (LV ejection fraction greater than 0.4). (Level of Evidence: C)

\section{Class III}

1. $\mathrm{PCl}$ of the infarct-related artery within 48 to $72 \mathrm{~h}$ after thrombolytic therapy without evidence of spontaneous or provocable ischemia. (Level of Evidence: C)

2. Routine $\mathrm{PCl}$ of the infarct-artery stenosis immediately after thrombolytic therapy. (Level of Evidence: A)

Class III
2. It is reasonable to perform $\mathrm{PCl}$ when there is documented clinical heart failure during the acute episode, even though subsequent evaluation shows preserved LV function (LV ejection fraction greater than 0.40 ). (Level of Evidence: $C$ )

1. PCl might be considered as part of an invasive strategy after fibrinolytic therapy. (Level of Evidence: $C$ )
Phrasing has been changed to reflect current terminology. Recommendation was upgraded to class Ila by the Writing Committee.
This recommendation has been upgraded and merged into the $\mathrm{llb}$ recommendation for $\mathrm{PCl}$ after fibrinolytic therapy below.

\subsubsection{PCI for Cardiogenic Shock}

\section{Class I}

None

\section{Class Ila}

Cardiogenic shock or hemodynamic instability. (Level of Evidence: B)

\section{Class I}

Primary $\mathrm{PCl}$ is recommended for patients less than 75 years old with ST elevation or LBBB who develop shock within 36 hours of MI and are suitable for revascularization that can be performed within 18 hours of shock, unless further support is futile because of the patient's wishes or contraindications/unsuitability for further invasive care. (Level of Evidence: A)

\section{Class Ila}

Primary $\mathrm{PCl}$ is reasonable for selected patients 75 years or older with ST elevation or LBBB who develop shock within 36 hours of $\mathrm{Ml}$ and are suitable for revascularization that can be performed within 18 hours of shock. Patients with good prior functional status who are suitable for revascularization and agree to invasive care may be selected for such an invasive strategy. (Level of Evidence: B)
This recommendation has been upgraded to class llb to reflect a possible benefit from improved technology. The Committee recognizes the potential benefit of this therapy but believes more data are needed to define outcomes of $\mathrm{PCl}$ after fibrinolytic therapy in the current era of improved antiplatelet, anticoagulant, and drug-eluting stent therapies.
Phrasing has been changed to reflect current terminology and the ACC/AHA Guidelines for the Management of Patients With ST-Elevation Myocardial Infarction (48-53).
Phrasing has been changed to reflect current technology and modified to be consistent with the ACC/AHA Guidelines for the Management of Patients With ST-Elevation Myocardial Infarction (48-53).

\subsection{Percutaneous Intervention in Patients With Prior Coronary Bypass Surgery}

\section{Class I}

Patients with early ischemia (usually within 30 days) after CABG (194). (Level of Evidence: $B$ )

\section{Class Ila}

1. Patients with ischemia occurring 1 to 3 years postoperatively and preserved LV function with discrete lesions in graft conduits. (Level of Evidence: $B$ )

2. Disabling angina secondary to new disease in a native coronary circulation. (If angina is not typical, the objective evidence of ischemia should be obtained.) (Level of Evidence: $B$ )

3. Patients with diseased vein grafts more than 3 years following CABG. (Level of Evidence: B)

\section{Class I}

1. When technically feasible, $\mathrm{PCl}$ should be performed in patients with early ischemia (usually within 30 days) after CABG. (Level of Evidence: $B$ )

2. It is recommended that distal embolic protection devices be used when technically feasible in patients undergoing $\mathrm{PCl}$ to saphenous vein grafts. (Level of Evidence: B)

\section{Class Ila}

1. $\mathrm{PCl}$ is reasonable in patients with ischemia that occurs 1 to 3 years after CABG and who have preserved LV function with discrete lesions in graft conduits. (Level of Evidence: $B$ )

2. $\mathrm{PCl}$ is reasonable in patients with disabling angina secondary to new disease in a native coronary circulation after CABG. (If angina is not typical, objective evidence of ischemia should be obtained.) (Level of Evidence: B)

3. $\mathrm{PCl}$ is reasonable in patients with diseased vein grafts more than 3 years after CABG. (Level of Evidence: B)

4. $\mathrm{PCl}$ is reasonable when technically feasible in patients with a patent left internal mammary artery graft who have clinically significant obstructions in other vessels. (Level of Evidence: C)
Phrasing has been changed to reflect current terminology.

New recommendation is based on several studies demonstrating efficacy of distal embolic protection devices in PCI to saphenous vein grafts $(65,66)$.

Phrasing has been changed to reflect current terminology.

Phrasing has been changed to reflect current terminology.

Phrasing has been changed to reflect current terminology.

This new recommendation addresses the feasibility of $\mathrm{PCl}$ to native circulation in the presence of a patent left internal mammary artery graft. 


\begin{tabular}{l}
\hline 2001 Recommendation \\
\hline Class III \\
1. PCI to chronic total vein graft
\end{tabular}
occlusions. (Level of Evidence: B)

2. Patients with multivessel disease, failure or multiple SVGs, and impaired LV function. (Level of Evidence: B)

2005 New or Revised Recommendation

Comments

\section{Class III}

1. $\mathrm{PCl}$ is not recommended in patients with prior $\mathrm{CABG}$ for chronic total vein graft occlusions. (Level of Evidence: $B$ )

2. $\mathrm{PCl}$ is not recommended in patients who have multiple target lesions with prior $\mathrm{CABG}$ and who have multivessel disease, failure of multiple SVGs, and impaired LV function unless repeat CABG poses excessive risk due to severe comorbid conditions. (Level of Evidence: $B$ )

\subsubsection{Intravascular Ultrasound Imaging (IVUS)}

\section{Class Ila}

1. Assessment of the adequacy of deployment of coronary stents, including the extent of stent apposition and determination of the minimum luminal diameter within the stent. (Level of Evidence: B) 2. Determination of the mechanism of stent restenosis (inadequate expansion vs. neointimal proliferation) and to enable selection of appropriate therapy (plaque ablation vs. repeat balloon expansion). (Level of Evidence: B) 3. Evaluation of coronary obstruction at a location difficult to image by angiography in a patient with a suspected flow-limiting stenosis. (Level of Evidence: C)

4. Assessment of a suboptimal angiographic result following $\mathrm{PCl}$. (Level of Evidence: C)

5. Diagnosis and management of coronary disease following cardiac transplantation. (Level of Evidence: C) 6. Establish presence and distribution of coronary calcium in patients for whom adjunctive rotational atherectomy is contemplated. (Level of Evidence: C)

7. Determination of plaque location and circumferential distribution for guidance of directional coronary atherectomy. (Level of Evidence: B)

\section{Class Ilb}

1. Determine extent of atherosclerosis in patients with characteristic anginal symptoms and a positive functional study with no focal stenoses or mild CAD on angiography. (Level of Evidence: C) 2. Preinterventional assessment of lesional characteristics and vessel dimensions as a means to select an optimal revascularization device. (Level of Evidence: C)

Class III

When angiographic diagnosis is clear and no interventional treatment is planned. (Level of Evidence: C)

\section{Class Ila}

1. IVUS is reasonable for the following:

a. Assessment of the adequacy of deployment of coronary stents, including the extent of stent apposition and determination of the minimum luminal diameter within the stent. (Level of Evidence: B)

b. Determination of the mechanism of stent restenosis (inadequate expansion versus neointimal proliferation) and to enable selection of appropriate therapy (vascular brachytherapy versus repeat balloon expansion). (Level of Evidence: B)

c. Evaluation of coronary obstruction at a location difficult to image by angiography in a patient with a suspected flow-limiting stenosis. (Level of Evidence: $C$ )

d. Assessment of a suboptimal angiographic result after PCI. (Level of Evidence: $\mathrm{C}$ )

e. Establishment of the presence and distribution of coronary calcium in patients for whom adjunctive rotational atherectomy is contemplated. (Level of Evidence: C) f. Determination of plaque location and circumferential distribution for guidance of directional coronary atherectomy. (Level of Evidence: B)
Phrasing has been changed to reflect current terminology.

Phrasing has been changed to reflect current technology, and considerations regarding risk of repeat CABG have been added (36).
Phrasing has been changed to reflect current terminology. The previous class lla recommendations for IVUS have been listed together in the recommendation rather than separately, with the exception that the Writing Committee has changed the recommendation to evaluate coronary disease after transplantation to class Ilb.

\section{Class IIb}

IVUS may be considered for the following:

a. Determination of the extent of atherosclerosis in patients with characteristic anginal symptoms and a positive functional study with no focal stenoses or mild CAD on angiography. (Level of Evidence: $\mathrm{C}$ )

b. Preinterventional assessment of lesional characteristics and vessel dimensions as a means to select an optimal revascularization device. (Level of Evidence: $C$ )

c. Diagnosis of coronary disease after cardiac transplantation. (Level of Evidence: $\mathrm{C}$ )

\section{Class III}

IVUS is not recommended when the angiographic diagnosis is clear and no interventional treatment is planned. (Level of Evidence: C)
Phrasing has been changed to reflect current terminology. The previous class $\mathrm{llb}$ recommendations for IVUS have been listed together in this recommendation rather than separately. The use of IVUS to evaluate coronary disease in transplant patients is now a class $\mathrm{llb}$ recommendation.
Phrasing has been changed to reflect current terminology. 


\begin{tabular}{|c|c|c|}
\hline 2001 Recommendation & 2005 New or Revised Recommendation & Comments \\
\hline \multicolumn{3}{|c|}{ 5.6.2. Coronary Artery Pressure and Flow: Use of Fractional Flow Reserve and Coronary Vasodilatory Reserve } \\
\hline Class Ila & Class Ila & \\
\hline $\begin{array}{l}\text { Assessment of the physiological effects } \\
\text { of intermediate coronary stenoses ( } 30 \text { to } \\
70 \% \text { luminal narrowing) in patients with } \\
\text { anginal symptoms. Coronary pressure or } \\
\text { Doppler velocimetry may also be useful } \\
\text { as an alternative to performing } \\
\text { noninvasive functional testing (e.g., when } \\
\text { the functional study is absent or } \\
\text { ambiguous) to determine whether an } \\
\text { intervention is warranted. (Level of } \\
\text { Evidence: B) }\end{array}$ & $\begin{array}{l}\text { It is reasonable to use intracoronary physiologic } \\
\text { measurements (Doppler ultrasound, fractional flow reserve) } \\
\text { in the assessment of the effects of intermediate coronary } \\
\text { stenoses ( } 30 \% \text { to } 70 \% \text { luminal narrowing) in patients with } \\
\text { anginal symptoms. Coronary pressure or Doppler } \\
\text { velocimetry may also be useful as an alternative to } \\
\text { performing noninvasive functional testing (e.g., when the } \\
\text { functional study is absent or ambiguous) to determine } \\
\text { whether an intervention is warranted. (Level of Evidence: } \\
\text { B) }\end{array}$ & Phrasing has been changed to reflect current terminology. \\
\hline Class Ilb & Class Ilb & \\
\hline $\begin{array}{l}\text { 1. Evaluation of the success of } \\
\text { percutaneous coronary } \\
\text { revascularization in restoring flow } \\
\text { reserve and to predict the risk of } \\
\text { restenosis. (Level of Evidence: } C \text { ) }\end{array}$ & $\begin{array}{l}\text { 1. Intracoronary physiologic measurements may be } \\
\text { considered for the evaluation of the success of } \mathrm{PCI} \text { in } \\
\text { restoring flow reserve and to predict the risk of restenosis. } \\
\text { (Level of Evidence: } C \text { ) }\end{array}$ & Phrasing has been changed to reflect current terminology. \\
\hline $\begin{array}{l}\text { 2. Evaluation of patients with anginal } \\
\text { symptoms without an apparent } \\
\text { angiographic culprit lesion. (Level of } \\
\text { Evidence: } C \text { ) }\end{array}$ & $\begin{array}{l}\text { 2. Intracoronary physiologic measurements may be } \\
\text { considered for the evaluation of patients with anginal } \\
\text { symptoms without an apparent angiographic culprit lesion. } \\
\text { (Level of Evidence: } C \text { ) }\end{array}$ & Phrasing has been changed to reflect current terminology. \\
\hline Class III & Class III & \\
\hline $\begin{array}{l}\text { Routine assessment of the severity of } \\
\text { angiographic disease in patients with a } \\
\text { positive, unequivocal noninvasive } \\
\text { functional study. (Level of Evidence: } C \text { ) }\end{array}$ & $\begin{array}{l}\text { Routine assessment with intracoronary physiologic measurements } \\
\text { such as Doppler ultrasound or fractional flow reserve to assess } \\
\text { the severity of angiographic disease in patients with a positive, } \\
\text { unequivocal noninvasive functional study is not recommended. } \\
\text { (Level of Evidence: } C \text { ) }\end{array}$ & Phrasing has been changed to reflect current terminology. \\
\hline
\end{tabular}

\section{Management of Patients Undergoing PCI}

6.1. Evolution of Technologies

6.1.1. Acute Results

\section{Class I}

It is recommended that distal embolic protection devices be used when technically feasible in patients undergoing $\mathrm{PCl}$ to saphenous vein grafts. (Level of Evidence: $B$ )
Published clinical trials using distal embolic protection devices confirm their benefit in improving cardiovascular outcomes among patients undergoing $\mathrm{PCI}$ to saphenous vein grafts $(65,66)$.

\subsection{Antiplatelet and Antithrombotic Adjunctive Therapies for PCI}

\subsubsection{Oral Antiplatelet Therapy}

The recommendations in this section appeared in table format in the 2001 guideline (see 2001 Table). The phrasing has been changed to reflect current terminology and to be consistent with new evidence and/or recommendations in the ACC/AHA Guidelines for the Management of Patients With ST-Elevation Myocardial Infarction and the ACC/AHA 2002 Guideline Update for Patients With Unstable Angina/Non-ST-Elevation Myocardial Infarction.

\section{Class I}

1. Patients already taking daily chronic aspirin therapy should take 75 to $325 \mathrm{mg}$ of aspirin before the $\mathrm{PCl}$ procedure is performed. (Level of Evidence: $A$ )

2. Patients not already taking daily chronic aspirin therapy should be given 300 to $325 \mathrm{mg}$ of aspirin at least 2 hours and preferably 24 hours before the $\mathrm{PCl}$ procedure is performed. (Level of Evidence: $C$ )

3. After the $\mathrm{PCl}$ procedure, in patients with neither aspirin resistance, allergy, nor increased risk of bleeding, aspirin $325 \mathrm{mg}$ daily should be given for at least 1 month after bare-metal stent implantation, 3 months after sirolimus-eluting stent implantation, and 6 months after paclitaxel-eluting stent implantation, after which daily chronic aspirin use should be continued indefinitely at a dose of 75 to $162 \mathrm{mg}$. (Level of Evidence: B)
A daily dose of $75 \mathrm{mg}$ of aspirin has been shown to result in improved cardiovascular outcomes similar to daily doses of $325 \mathrm{mg}$ but with fewer bleeding complications (67-69).

Higher doses of aspirin are recommended for patients not already taking aspirin therapy immediately before $\mathrm{PCl}$ procedures.

The doses and duration of aspirin therapy recommended herein are derived from those used for US Food and Drug Administration approval of the specific stent types noted in the recommendation. Daily chronic aspirin therapy is based on recommendations in the ACC/AHA Guidelines for the Management of Patients With ST-Elevation Myocardial Infarction and evidence indicating that aspirin therapy in dosages as low as $75 \mathrm{mg}$ per day yields outcomes similar to those achieved with $325 \mathrm{mg}$ per day but with fewer side effects $(67,69-71)$. 


\section{New or Revised Recommendation}

4. A loading dose of clopidogrel should be administered before $\mathrm{PCl}$ is performed. (Level of Evidence: A) An oral loading dose of $300 \mathrm{mg}$, administered at least 6 hours before the procedure, has the best established evidence of efficacy. (Level of Evidence: B)

5. In patients who have undergone $\mathrm{PCl}$, clopidogrel $75 \mathrm{mg}$ daily should be given for at least 1 month after bare-metal stent implantation (unless the patient is at increased risk for bleeding; then it should be given for a minimum of 2 weeks), 3 months after sirolimus stent implantation, and 6 months after paclitaxel stent implantation, and ideally up to 12 months in patients who are not at high risk of bleeding. (Level of Evidence: $B$ )

\section{Class Ila}

1. If clopidogrel is given at the time of procedure, supplementation with GP Ilb/lla receptor antagonists can be beneficial to facilitate earlier platelet inhibition than with clopidogrel alone. (Level of Evidence: B)

2. For patients with an absolute contraindication to aspirin, it is reasonable to give a $300-\mathrm{mg}$ loading dose of clopidogrel, administered at least 6 hours before $\mathrm{PCl}$, and/or GP Ilb/lla antagonists, administered at the time of PCl. (Level of Evidence: $\mathrm{C}$ )

3. When a loading dose of clopidogrel is administered, a regimen of greater than $300 \mathrm{mg}$ is reasonable to achieve higher levels of antiplatelet activity more rapidly, but the efficacy and safety compared with a 300-mg loading dose are less established. (Level of Evidence: $C$ )

4. It is reasonable that patients undergoing brachytherapy be given daily clopidogrel $75 \mathrm{mg}$ indefinitely and daily aspirin 75 to $325 \mathrm{mg}$ indefinitely unless there is significant risk for bleeding. (Level of Evidence: $\mathrm{C}$ )

\section{Class Ilb}

In patients in whom subacute thrombosis may be catastrophic or lethal (unprotected left main, bifurcating left main, or last patent coronary vessel), platelet aggregation studies may be considered and the dose of clopidogrel increased to $150 \mathrm{mg}$ per day if less than $50 \%$ inhibition of platelet aggregation is demonstrated. (Level of Evidence: $\mathrm{C}$ )

\section{Comments}

Clopidogrel is an important adjunctive therapy for patients undergoing $\mathrm{PCl}$ with stent placement. The best evidence of efficacy exists for $300 \mathrm{mg}$ given at least 6 hours before $\mathrm{PCl}$ is performed $(68,69,72)$.

Clopidogrel therapy in the dosage of $75 \mathrm{mg}$ daily should be given after stent placement to all patients. The duration of therapy varies for each stent and is based on data from clinical trials used for US Food and Drug Administration approval of that stent $(67,69-71)$.

When clopidogrel is given at the time of a $\mathrm{PCl}$ procedure, supplementation with glycoprotein Ilb/Illa receptor antagonists can be beneficial, especially among high-risk patients $(73,74)$.

A significant number of patients will have resistance to aspirin. The strongest evidence for clopidogrel benefit exists for doses of 300 $\mathrm{mg}$ given at least 6 hours before the procedure.

Many patients receive clopidogrel therapy at the time of PCl in dosages greater than $600 \mathrm{mg}$. Although more pronounced inhibition of platelet function has been demonstrated for doses of clopidogrel greater than $300 \mathrm{mg}$, the safety of these higher doses and their benefits on clinical outcome are not fully established.

Subacute or later thrombosis has been observed in patients undergoing brachytherapy, and for this reason long-term antiplatelet therapy is recommended.

Clopidogrel resistance is a significant problem, and owing to its contribution to catastrophic clinical outcomes, the Writing Committee recommends studies be performed with increases in clopidogrel dose being recommended for use in those with higher-risk lesions.

\subsubsection{Glycoprotein Ilb/Illa Inhibitors}

The recommendations in this section appeared in table format in the 2001 guideline (see 2001 Table). The phrasing has been changed to reflect current terminology and to be consistent with new evidence and/or recommendations in the ACC/AHA Guidelines for the Management of Patients With ST-Elevation Myocardial Infarction and the ACC/AHA 2002 Guideline Update for the Management of Patients With Unstable Angina/ Non-ST-Elevation Myocardial Infarction.

\section{Class I}

In patients with UA/NSTEMI undergoing PCI without clopidogrel administration, a GP IIb/Illa inhibitor (abciximab, eptifibatide, or tirofiban) should be administered. (Level of Evidence: A)§ §It is acceptable to administer the GP IIb/llla inhibitor before performance of the diagnostic angiogram ("upstream treatment") or just before PCI ("in-lab treatment").

\section{Class Ila}

1. In patients with UA/NSTEMI undergoing PCI with clopidogrel administration, it is reasonable to administer a GP IIb/llla inhibitor (abciximab, eptifibatide, or tirofiban). (Level of Evidence: $B) \S$

§lt is acceptable to administer the GP Ilb/lla inhibitor before performance of the diagnostic angiogram ("upstream treatment") or just before PCl ("in-lab treatment").

2. In patients with STEMl undergoing $\mathrm{PCl}$, it is reasonable to administer abciximab as early as possible. (Level of Evidence: B)
This recommendation and phrasing are compatible with the ACC/AHA 2002 Guideline Update for the Management of Patients With Unstable Angina and Non-ST-Segment Myocardial Infarction and current evidence from randomized clinical trials. The benefits of GP IIb/lla inhibition are especially efficacious when clopidogrel is not given (37).
See above (37).

Recommendation has been added for consistency with the ACC/AHA Guidelines for the Management of Patients With ST-Elevation Myocardial Infarction (57,75-78). 


2001 Recommendation 2005 New or Revised Recommendation

3. In patients undergoing elective $\mathrm{PCl}$ with stent placement, it is reasonable to administer a GP Ill/llla inhibitor (abciximab, eptifibatide, or tirofiban). (Level of Evidence: $B$ )

Class Ilb

In patients with STEMl undergoing $\mathrm{PCl}$, treatment with eptifibatide or tirofiban may be considered. (Level of Evidence: $C$ )

\section{Comments}

Phrasing has been changed to reflect current terminology, especially in a high-risk patient $(79,80)$.

Recommendation has been added for consistency with the ACC/AHA Guidelines for the Management of Patients With ST-Elevation Myocardial Infarction.

\subsubsection{Antithrombotic Therapy}

6.2.3.1 Unfractionated Heparin, Low-Molecular-Weight Heparin, and Bivalirudin

\section{The recommendations in this section appeared in table format in the 2001 guideline (see 2001 Table). The phrasing has been changed to reflect current terminology and to be consistent with new evidence and/or recommendations in the ACC/AHA Guidelines for the Management of Patients With ST-Elevation Myocardial Infarction and the ACC/AHA 2002 Guideline Update for the Management of Patients With Unstable Angina/Non-ST- Elevation Myocardial Infarction.} Class I

1. Unfractionated heparin should be administered to patients undergoing PCl. (Level of Evidence: C)

2. For patients with heparin-induced thrombocytopenia, it is recommended that bivalirudin or argatroban be used to replace heparin. (Level of Evidence: B)

Phrasing has been changed to reflect current terminology.

Bivalirudin and argatroban are established therapies in place of heparin among patients with heparin-induced thrombocytopenia (81, 82).
Class Ila None

\section{Class Ila}

1. It is reasonable to use bivalirudin as an alternative to unfractionated heparin and glycoprotein Ilb/llla antagonists in low-risk patients undergoing elective $\mathrm{PCl}$. (Level of Evidence: $B$ ) 2. Low-molecular-weight heparin is a reasonable alternative to unfractionated heparin in patients with UA/NSTEMI undergoing PCl. (Level of Evidence: B)

Class Ilb

Class Ilb

None

Low-molecular-weight heparin may be considered as an alternative to unfractionated heparin in patients with STEMI undergoing PCl. (Level of Evidence: B)
New recommendation is based on data from a clinical trial (REPLACE-2) indicating bivalirudin is an acceptable alternative to heparin and GP IIb/lla antagonists in low-risk patients undergoing $\mathrm{PCl}(83)$.

Recommendation from the ACC/AHA 2002 Guideline Update for the Management of Patients With Unstable Angina and Non-ST-Segment Myocardial Infarction has been approved by this Writing Committee and included in these guidelines for consistency.

Recommendation from the ACC/AHA Guidelines for the Management of Patients With ST-Elevation Myocardial Infarction has been approved by this Writing Committee and included in these guidelines for consistency.

6.3.4. Left Main CAD

Class Ila Class Ila

None It is reasonable that patients undergoing $\mathrm{PCl}$ to unprotected left main coronary obstructions be followed up with coronary angiography between 2 and 6 months after PCl. (Level of Evidence: C)

Patients undergoing $\mathrm{PCl}$ to an unprotected left main coronary artery are at higher risk for adverse events and should be monitored carefully. On the basis of experience and opinion in the available reports, the Writing Committee recommends angiography be performed between 2 and 6 months after $\mathrm{PCl}$.

\subsubsection{Management Strategies for Restenosis After PTCA}

\begin{tabular}{lll}
\hline Class Ila & Class Ila & \\
None & $\begin{array}{ll}\text { It is reasonable to consider that patients who develop } \\
\text { restenosis after PTCA or PTCA with atheroablative devices are }\end{array}$ & $\begin{array}{l}\text { This new recommendation reflects data indicating a significant } \\
\text { reduction in target-lesion revascularization and restenosis for patients } \\
\text { candidates for repeat coronary intervention with intracoronary } \\
\text { stents if anatomic factors are appropriate. (Level of Evidence: B) }\end{array}$ \\
$\begin{array}{ll}\text { undergoing bare-metal stent placement compared with PTCA for } \\
\text { restenosis after PTCA (84). }\end{array}$
\end{tabular}

\subsubsection{Drug-Eluting Stents}

\begin{tabular}{ll}
\hline Class I & Class I \\
\hline None & $\begin{array}{l}\text { A drug-eluting stent should be considered as an alternative } \\
\text { to the bare-metal stent in subsets of patients in whom trial } \\
\text { data suggest efficacy. (Level of Evidence: A) }\end{array}$
\end{tabular}

\section{Class Ilb Class Illb}

None
A drug-eluting stent may be considered for use in anatomic settings in which the usefulness, effectiveness, and safety have not been fully documented in published trials. (Level of Evidence: C)
New recommendation since the 2001 ACC/AHA Guidelines for Percutaneous Coronary Intervention. Evidence continues to accumulate that supports the use of drug-eluting stents (DES) versus bare-metal stents in certain subsets in which DES results and outcomes are better (70, 71, 85-97).

The data that a DES can improve clinical outcomes for $\mathrm{PCl}$ are generally strong. However, DESs have not undergone evaluation for use in all clinical situations and anatomic settings. 


\begin{tabular}{|c|c|c|}
\hline 2001 Recommendation & 2005 New or Revised Recommendation & Comments \\
\hline \multicolumn{3}{|c|}{ 7.3.6.2 Drug-Eluting Stents for the Management of In-Stent Restenosis } \\
\hline Class Ila & Class Ila & \\
\hline None & $\begin{array}{l}\text { Brachytherapy can be useful as a safe and effective treatment } \\
\text { for in-stent restenosis. (Level of Evidence: A) }\end{array}$ & $\begin{array}{l}\text { This is a new recommendation since the } 2001 \\
\text { ACC/AHA Guidelines for Percutaneous Coronary } \\
\text { Intervention based on evidence supporting the efficacy } \\
\text { of brachytherapy in the treatment of in-stent restenosis } \\
(102-109) \text {. }\end{array}$ \\
\hline
\end{tabular}

2001 TABLE. Recommendations for Pharmacological Management of Patients Undergoing PCl-For Comparison Purposes Only (Deleted From 2005 Guideline)

\begin{tabular}{|c|c|c|c|c|c|}
\hline \multirow[b]{3}{*}{ Drugs } & \multicolumn{5}{|c|}{ Clinical Status } \\
\hline & \multirow[b]{2}{*}{$\begin{array}{l}\text { Class I } \\
\text { Angina }\end{array}$} & \multicolumn{4}{|c|}{ Transmural Myocardial Infarction } \\
\hline & & $\begin{array}{c}\text { Class II-IV } \\
\text { Angina, Unstable } \\
\text { Angina, NSTEMI }\end{array}$ & $\begin{array}{c}\text { Acute } \\
\text { Phase Ml }\end{array}$ & $\begin{array}{c}\text { After } \\
\text { Thrombolysis }\end{array}$ & $\begin{array}{c}\text { Hospital } \\
\text { Management } \\
\text { Phase }\end{array}$ \\
\hline Aspirin & $I^{*}$ & I & I & 1 & I \\
\hline $\begin{array}{l}\text { Ticlopidine, } \\
\text { Clopidogrel† }\end{array}$ & १ & I & 1 & I & I§ \\
\hline Warfarin\| & \|\|$\|$ & III & III & $\|$ & $\mid \eta$ \\
\hline $\begin{array}{c}\text { GP blockers\# } \\
\text { Abciximab } \\
\text { Tirofiban } \\
\text { Eptifibatide }\end{array}$ & $\|$ & I & $\|$ & I & III \\
\hline Unfractionated heparin ${ }^{\star \star}$ & I & I & I & ॥ & Ill†† \\
\hline
\end{tabular}

Note: This table has been deleted from the 2005 PCI Guideline Update. The recommendations in this table were updated or deleted, as determined by the writing committee, and included in the $2005 \mathrm{PCI}$ Guideline Update in the recommendation list.

${ }^{*}$ Roman numerals indicate ACC/AHA class indication I, II, or III.

†In conjunction with stenting.

$\ddagger$ To be given $24-48 \mathrm{~h}$ before planned stenting, if possible.

§For 2 to 4 weeks after stent placement.

१For patients without atrial fibrillation or other pre-existing clinical indications.

|For patients with anterior myocardial wall motion abnormalities or LV thrombus.

\#Every indication may not apply to all individual agents.

**Low-molecular-weight heparin is under investigation to replace unfractionated heparin.

††Other noncoronary thrombotic complications (eg, thrombophlebitis).

\section{Appendix. Abbreviations}

$C A B G$

$C A D$

CK

$D E S$

$E C G$

$G P$

$H F$

IVUS coronary artery bypass graft surgery

coronary artery disease

creatine kinase

drug-eluting stent

electrocardiogram

glycoprotein

heart failure

intravascular ultrasound

left anterior descending artery

\begin{tabular}{|c|c|}
\hline$\angle B B B$ & left bundle-branch block \\
\hline$L V$ & left ventricular \\
\hline$M B$ & $\begin{array}{l}\text { cardiac muscle isoenzyme of } \\
\text { creatine kinase }\end{array}$ \\
\hline MI & myocardial infarction \\
\hline MR & mitral regurgitation \\
\hline NSTEMI & $\begin{array}{l}\text { non-ST-elevation myocardial } \\
\text { infarction }\end{array}$ \\
\hline $\mathrm{PCl}$ & percutaneous coronary intervention \\
\hline STEMI & ST-elevation myocardial infarction \\
\hline$U A$ & unstable angina \\
\hline
\end{tabular}




\section{References}

1. Alpert JS, Thygesen K, Antman E, Bassand JP. Myocardial infarction redefined-a consensus document of The Joint European Society of Cardiology/American College of Cardiology Committee for the redefinition of myocardial infarction. J Am Coll Cardiol 2000;36:959-69.

2. Selvanayagam JB, Porto I, Channon K, et al. Troponin elevation after percutaneous coronary intervention directly represents the extent of irreversible myocardial injury: insights from cardiovascular magnetic resonance imaging. Circulation 2005;111:1027-32.

3. Bertinchant JP, Polge A, Ledermann B, et al. Relation of minor cardiac troponin I elevation to late cardiac events after uncomplicated elective successful percutaneous transluminal coronary angioplasty for angina pectoris. Am J Cardiol 1999;84:51-7.

4. Garbarz E, Iung B, Lefevre G, et al. Frequency and prognostic value of cardiac troponin I elevation after coronary stenting. Am J Cardiol 1999;84:515-8.

5. Fuchs S, Kornowski R, Mehran R, et al. Prognostic value of cardiac troponin-I levels following catheter-based coronary interventions. Am J Cardiol 2000;85:1077-82.

6. Cantor WJ, Newby LK, Christenson RH, et al. Prognostic significance of elevated troponin I after percutaneous coronary intervention. J Am Coll Cardiol 2002;39:1738-44.

7. Wu AH, Boden WE, McKay RG. Long-term follow-up of patients with increased cardiac troponin concentrations following percutaneous coronary intervention. Am J Cardiol 2002;89:1300-2.

8. Kizer JR, Muttrej MR, Matthai WH, et al. Role of cardiac troponin T in the long-term risk stratification of patients undergoing percutaneous coronary intervention. Eur Heart J 2003;24:1314-22.

9. Ricciardi MJ, Davidson CJ, Gubernikoff G, et al. Troponin I elevation and cardiac events after percutaneous coronary intervention. Am Heart J 2003; 145:522-8.

10. Kini AS, Lee P, Marmur JD, et al. Correlation of postpercutaneous coronary intervention creatine kinase-MB and troponin I elevation in predicting mid-term mortality. Am J Cardiol 2004;93:18-23.

11. Vakili BA, Kaplan R, Brown DL. Volume-outcome relation for physicians and hospitals performing angioplasty for acute myocardial infarction in New York state. Circulation 2001;104:2171-6.

12. Vakili BA, Brown DL. Relation of total annual coronary angioplasty volume of physicians and hospitals on outcomes of primary angioplasty for acute myocardial infarction (data from the 1995 Coronary Angioplasty Reporting System of the New York State Department of Health). Am J Cardiol 2003;91:726-8.

13. Cannon CP, Gibson CM, Lambrew CT, et al. Relationship of symptom-onsetto-balloon time and door-to-balloon time with mortality in patients undergoing angioplasty for acute myocardial infarction. JAMA 2000;283:2941-7.

14. Jollis JG, Peterson ED, Nelson CL, et al. Relationship between physician and hospital coronary angioplasty volume and outcome in elderly patients. Circulation 1997;95:2485-91.

15. Klein LW, Schaer GL, Calvin JE, et al. Does low individual operator coronary interventional procedural volume correlate with worse institutional procedural outcome? J Am Coll Cardiol 1997;30:870-7.

16. Magid DJ, Calonge BN, Rumsfeld JS, et al. Relation between hospital primary angioplasty volume and mortality for patients with acute MI treated with primary angioplasty vs thrombolytic therapy. JAMA 2000;284:3131-8.

17. Canto JG, Every NR, Magid DJ, et al. The volume of primary angioplasty procedures and survival after acute myocardial infarction: National Registry of Myocardial Infarction 2 Investigators. N Engl J Med 2000;342:1573-80.

18. Klinke WP, Hui W. Percutaneous transluminal coronary angioplasty without on-site surgical facilities. Am J Cardiol 1992;70:1520-5.

19. Meier B, Urban P, Dorsaz PA, Favre J. Surgical standby for coronary balloon angioplasty. JAMA 1992;268:741-5.

20. Iniguez A, Macaya C, Hernandez R, et al. Comparison of results of percutaneous transluminal coronary angioplasty with and without selective requirement of surgical standby. Am J Cardiol 1992;69:1161-5.

21. Hubner PJ, Balcon R, Dyet J, Dymond DS, et al. Surgical cover for percutaneous transluminal coronary angioplasty. Br Heart J 1992;68: $339-41$.

22. Sowton E, de Bono D, Gribbin B, O'Keeffe B, et al. Coronary angioplasty in the United Kingdom. Br Heart J 1991;66:325-31.

23. Loubeyre C, Morice MC, Berzin B, et al. Emergency coronary artery bypass surgery following coronary angioplasty and stenting: results of a French multicenter registry. Catheter Cardiovasc Interv 1999;47:441-8.

24. Vogt A, Bonzel T, Harmjanz D, et al. PTCA registry of German community hospitals. Arbeitsgemeinschaft Leitender Kardiologischer Krankenhausarzte (ALKK) Study Group. Eur Heart J 1997;18:1110-4.
25. Dellavalle A, Steffenino G, Ribichini F, Russo P, Uslenghi E. Elective coronary angioplasty with and without surgical standby: clinical and angiographic criteria for the selection of patients. Coron Artery Dis 1995;6:513-20.

26. Richardson SG, Morton P, Murtagh JG, O'Keeffe DB, Murphy P, Scott ME. Management of acute coronary occlusion during percutaneous transluminal coronary angioplasty: experience of complications in a hospital without on site facilities for cardiac surgery (see comments). BMJ 1990;300:355-8.

27. Reifart N, Preusler W, Schwarz F, et al. A large center experience of coronary angioplasty without on-site surgical standby. In: Topol EJ, Serruys PW, editors. Current Review of Interventional Cardiology. Philadelphia, PA: Current Medicine, 1995:296-303.

28. Yusuf S, Wittes J, Probstfield J, Tyroler HA. Analysis and interpretation of treatment effects in subgroups of patients in randomized clinical trials. JAMA 1991;266:93-8.

29. Wennberg DE, Lucas FL, Siewers AE, Kellett MA, Malenka DJ. Outcomes of percutaneous coronary interventions performed at centers without and with onsite coronary artery bypass graft surgery. JAMA 2004;292:1961-8.

30. Fox KA, Poole-Wilson PA, Henderson RA, et al. Interventional versus conservative treatment for patients with unstable angina or non-STelevation myocardial infarction: the British Heart Foundation RITA 3 randomised trial. Randomized Intervention Trial of unstable Angina. Lancet 2002;360:743-51.

31. Hueb W, Soares PR, Gersh BJ, et al. The Medicine, Angioplasty, or Surgery Study (MASS-II): a randomized, controlled clinical trial of three therapeutic strategies for multivessel coronary artery disease: one-year results. J Am Coll Cardiol 2004;43:1743-51.

32. Chieffo A, Stankovic G, Bonizzoni E, et al. Early and mid-term results of drug-eluting stent implantation in unprotected left main. Circulation 2005;111:791-5.

33. Park SJ, Kim YH, Lee BK, et al. Sirolimus-eluting stent implantation for unprotected left main coronary artery stenosis: comparison with bare metal stent implantation. J Am Coll Cardiol 2005;45:351-6.

34. Silvestri M, Barragan P, Sainsous J, et al. Unprotected left main coronary artery stenting: immediate and medium-term outcomes of 140 elective procedures. J Am Coll Cardiol 2000;35:1543-50.

35. Tan WA, Tamai H, Park SJ, et al. Long-term clinical outcomes after unprotected left main trunk percutaneous revascularization in 279 patients. Circulation 2001;104:1609-14.

36. Eagle KA, Guyton RA, Davidoff R, et al. ACC/AHA 2004 guideline update for coronary artery bypass graft surgery—summary article: a report of the American College of Cardiology/American Heart Association Task Force on Practice Guidelines (Committee to Update the 1999 Guidelines for Coronary Artery Bypass Graft Surgery). J Am Coll Cardiol 2004;44:1146-310.

37. Braunwald E, Antman EM, Beasley JW, et al. ACC/AHA 2002 guideline update for the management of patients with unstable angina and non-ST-segment elevation myocardial infarction: a report of the American College of Cardiology/American Heart Association Task Force on Practice Guidelines (Committee on the Management of Patients With Unstable Angina) 2002. Available at: http://www.acc.org/ clinical/guidelines/unstable/incorporated/index.htm. Accessed January 10,2005 .

38. Invasive compared with non-invasive treatment in unstable coronaryartery disease: FRISC II prospective randomised multicentre study. FRagmin and Fast Revascularisation during InStability in Coronary artery disease Investigators. Lancet 1999;354:708-15.

39. Cannon CP, Weintraub WS, Demopoulos LA, et al. Comparison of early invasive and conservative strategies in patients with unstable coronary syndromes treated with the glycoprotein IIb/IIIa inhibitor tirofiban. N Engl J Med 2001;344:1879-87.

40. de Lezo JS, Medina A, Pan M, et al. Rapamycin-eluting stents for the treatment of unprotected left main coronary disease. Am Heart J 2004;148:481-5.

41. Black A, Cortina R, Bossi I, Choussat R, Fajadet J, Marco J. Unprotected left main coronary artery stenting: correlates of midterm survival and impact of patient selection. J Am Coll Cardiol 2001;37:832-8.

42. Takagi T, Stankovic G, Finci L, et al. Results and long-term predictors of adverse clinical events after elective percutaneous interventions on unprotected left main coronary artery. Circulation 2002;106:698-702.

43. Park SJ, Park SW, Hong MK, et al. Long-term (three-year) outcomes after stenting of unprotected left main coronary artery stenosis in patients with normal left ventricular function. Am J Cardiol 2003;91:12-6. 
44. Keeley EC, Boura JA, Grines CL. Primary angioplasty versus intravenous thrombolytic therapy for acute myocardial infarction: a quantitative review of 23 randomised trials. Lancet 2003;361:13-20.

45. Nallamothu BK, Bates ER. Percutaneous coronary intervention versus fibrinolytic therapy in acute myocardial infarction: is timing (almost) everything? Am J Cardiol 2003;92:824-6.

46. De LG, Suryapranata H, Ottervanger JP, Antman EM. Time delay to treatment and mortality in primary angioplasty for acute myocardial infarction: every minute of delay counts. Circulation 2004;109:1223-5.

47. Berger PB, Ellis SG, Holmes DR, Jr., et al. Relationship between delay in performing direct coronary angioplasty and early clinical outcome in patients with acute myocardial infarction: results from the global use of strategies to open occluded arteries in Acute Coronary Syndromes (GUSTO-IIb) trial. Circulation 1999;100:14-20.

48. Hochman JS, Sleeper LA, Webb JG, et al. Early revascularization in acute myocardial infarction complicated by cardiogenic shock. SHOCK Investigators. Should We Emergently Revascularize Occluded Coronaries for Cardiogenic Shock (see comments). N Engl J Med 1999;341:625-34.

49. Hochman JS, Sleeper LA, White HD, et al. One-year survival following early revascularization for cardiogenic shock. JAMA 2001;285:190-2.

50. Urban P, Stauffer JC, Bleed D, et al. A randomized evaluation of early revascularization to treat shock complicating acute myocardial infarction. The (Swiss) Multicenter Trial of Angioplasty for Shock(S)MASH. Eur Heart J 1999;20:1030-8.

51. Dzavik V, Sleeper LA, Picard MH, et al. Outcome of patients aged $\geq 75$ years in the SHould we emergently revascularize Occluded Coronaries in cardiogenic shocK (SHOCK) trial: do elderly patients with acute myocardial infarction complicated by cardiogenic shock respond differently to emergent revascularization? Am Heart J 2005;149:1128-34.

52. Dauerman HL, Goldberg RJ, Malinski M, Yarzebski J, Lessard D, Gore JM. Outcomes and early revascularization for patients $\geq 65$ years of age with cardiogenic shock. Am J Cardiol 2001;87:844-8.

53. Dauerman HL, Ryan TJ, Jr., Piper WD, et al. Outcomes of percutaneous coronary intervention among elderly patients in cardiogenic shock: a multicenter, decade-long experience. J Invasive Cardiol 2003;15:380-4.

54. Wu AH, Parsons L, Every NR, Bates ER. Hospital outcomes in patients presenting with congestive heart failure complicating acute myocardial infarction: a report from the Second National Registry of Myocardial Infarction (NRMI-2). J Am Coll Cardiol 2002;40:1389-94.

55. Bengtson JR, Kaplan AJ, Pieper KS, et al. Prognosis in cardiogenic shock after acute myocardial infarction in the interventional era. J Am Coll Cardiol 1992;20:1482-9.

56. Lee L, Erbel R, Brown TM, Laufer N, Meyer J, O'Neill WW. Multicenter registry of angioplasty therapy of cardiogenic shock: initial and long-term survival. J Am Coll Cardiol 1991;17:599-603.

57. Montalescot G, Barragan P, Wittenberg O, et al. Platelet glycoprotein $\mathrm{IIb} / \mathrm{III}$ inhibition with coronary stenting for acute myocardial infarction. N Engl J Med 2001;344:1895-903.

58. Brodie BR, Stuckey TD, Hansen C, Muncy D. Benefit of coronary reperfusion before intervention on outcomes after primary angioplasty for acute myocardial infarction. Am J Cardiol 2000;85:13-8.

59. Stone GW, Mehran R, Dangas G, Lansky AJ, Kornowski R, Leon MB. Differential impact on survival of electrocardiographic Q-wave versus enzymatic myocardial infarction after percutaneous intervention: a device-specific analysis of 7147 patients. Circulation 2001;104:642-7.

60. Gibson CM. A union in reperfusion: the concept of facilitated percutaneous coronary intervention. J Am Coll Cardiol 2000;36:1497-9.

61. Herrmann HC, Moliterno DJ, Ohman EM, et al. Facilitation of early percutaneous coronary intervention after reteplase with or without abciximab in acute myocardial infarction: results from the SPEED (GUSTO-4 Pilot) Trial. J Am Coll Cardiol 2000;36:1489-96.

62. Kastrati A, Mehilli J, Schlotterbeck K, et al. Early administration of reteplase plus abciximab vs abciximab alone in patients with acute myocardial infarction referred for percutaneous coronary intervention: a randomized controlled trial. JAMA 2004;291:947-54.

63. Le May MR, Wells GA, Labinaz M, et al. Combined angioplasty and pharmacological intervention versus thrombolysis alone in acute myocardial infarction (CAPITAL AMI study). J Am Coll Cardiol 2005;46:417-24.

64. Madsen JK, Grande P, Saunamaki K, et al. Danish multicenter randomized study of invasive versus conservative treatment in patients with inducible ischemia after thrombolysis in acute myocardial infarction (DANAMI). DANish trial in Acute Myocardial Infarction. Circulation 1997;96:748-55.

65. Baim DS, Wahr D, George B, et al. Randomized trial of a distal embolic protection device during percutaneous intervention of saphenous vein aorto-coronary bypass grafts. Circulation 2002;105:1285-90.
66. Stone GW, Rogers C, Hermiller J, et al. Randomized comparison of distal protection with a filter-based catheter and a balloon occlusion and aspiration system during percutaneous intervention of diseased saphenous vein aortocoronary bypass grafts. Circulation 2003;108:548-53.

67. Yusuf S, Zhao F, Mehta SR, Chrolavicius S, Tognoni G, Fox KK. Effects of clopidogrel in addition to aspirin in patients with acute coronary syndromes without ST-segment elevation. N Engl J Med 2001;345:494-502.

68. Mehta SR, Yusuf S, Peters RJ, et al. Effects of pretreatment with clopidogrel and aspirin followed by long-term therapy in patients undergoing percutaneous coronary intervention: the PCI-CURE study. Lancet 2001;358:527-33.

69. Steinhubl SR, Berger PB, Mann JT, III, et al. Early and sustained dual oral antiplatelet therapy following percutaneous coronary intervention: a randomized controlled trial. JAMA 2002;288:2411-20.

70. Stone GW, Ellis SG, Cox DA, et al. One-year clinical results with the slow-release, polymer-based, paclitaxel-eluting TAXUS stent: the TAXUS-IV trial. Circulation 2004;109:1942-7.

71. Holmes DR, Jr., Leon MB, Moses JW, et al. Analysis of 1-year clinical outcomes in the SIRIUS trial: a randomized trial of a sirolimus-eluting stent versus a standard stent in patients at high risk for coronary restenosis. Circulation 2004;109:634-40.

72. Patti G, Colonna G, Pasceri V, Pepe LL, Montinaro A, Di SG. Randomized trial of high loading dose of clopidogrel for reduction of periprocedural myocardial infarction in patients undergoing coronary intervention: results from the ARMYDA-2 (Antiplatelet therapy for Reduction of MYocardial Damage during Angioplasty) study. Circulation 2005;111:2099-106.

73. Kastrati A, Mehilli J, Schuhlen H, et al. A clinical trial of abciximab in elective percutaneous coronary intervention after pretreatment with clopidogrel. N Engl J Med 2004;350:232-8.

74. Gurbel PA, Bliden KP, Zaman KA, Yoho JA, Hayes KM, Tantry US. Clopidogrel loading with eptifibatide to arrest the reactivity of platelets: results of the Clopidogrel Loading With Eptifibatide to Arrest the Reactivity of Platelets (CLEAR PLATELETS) study. Circulation 2005;111:1153-9.

75. Brener SJ, Barr LA, Burchenal JE, et al. Randomized, placebocontrolled trial of platelet glycoprotein IIb/IIIa blockade with primary angioplasty for acute myocardial infarction. ReoPro and Primary PTCA Organization and Randomized Trial (RAPPORT) Investigators. Circulation 1998;98:734-41

76. Neumann FJ, Kastrati A, Schmitt C, et al. Effect of glycoprotein IIb/III receptor blockade with abciximab on clinical and angiographic restenosis rate after the placement of coronary stents following acute myocardial infarction. J Am Coll Cardiol 2000;35:915-21.

77. Stone GW, Grines CL, Cox DA, et al. Comparison of angioplasty with stenting, with or without abciximab, in acute myocardial infarction. N Engl J Med 2002;346:957-66.

78. Antoniucci D, Santoro GM, Bolognese L, Valenti R, Trapani M, Fazzini PF. A clinical trial comparing primary stenting of the infarct-related artery with optimal primary angioplasty for acute myocardial infarction: results from the Florence Randomized Elective Stenting in Acute Coronary Occlusions (FRESCO) trial. J Am Coll Cardiol 1998;31:1234-9.

79. Kong DF, Hasselblad V, Harrington RA, et al. Meta-analysis of survival with platelet glycoprotein IIb/IIIa antagonists for percutaneous coronary interventions. Am J Cardiol 2003;92:651-5.

80. Karvouni E, Katritsis DG, Ioannidis JP. Intravenous glycoprotein $\mathrm{IIb} / \mathrm{III}$ a receptor antagonists reduce mortality after percutaneous coronary interventions. J Am Coll Cardiol 2003;41:26-32.

81. Angiomax (bivalirudin) for injection. Package Insert. The Medicine Company, Parsippany, NJ. Available at: http://www.themedicinescompany. com/ products_content/PN16019gt2.pdf. Accessed May 27, 2005.

82. Argatroban Injection. Prescribing Information. GlaxoSmithKline, Research Triangle, NC. Available at: http://us.gsk.com/products/assets/ us_argatroban.pdf. Accessed May 27, 2005.

83. Lincoff AM, Bittl JA, Harrington RA, et al. Bivalirudin and provisional glycoprotein IIb/IIIa blockade compared with heparin and planned glycoprotein IIb/IIIa blockade during percutaneous coronary intervention: REPLACE-2 randomized trial. JAMA 2003;289:853-63.

84. Erbel R, Haude M, Hopp HW, et al. Coronary-artery stenting compared with balloon angioplasty for restenosis after initial balloon angioplasty. Restenosis Stent Study Group (see comments). N Engl J Med 1998;339:1672-8.

85. Sousa JE, Costa MA, Abizaid AC, et al. Sustained suppression of neointimal proliferation by sirolimus-eluting stents: one-year angiographic and intravascular ultrasound follow-up. Circulation 2001;104:2007-11.

86. Morice MC, Serruys PW, Sousa JE, et al. A randomized comparison of a sirolimus-eluting stent with a standard stent for coronary revascularization. N Engl J Med 2002;346:1773-80. 
87. Schampaert E, Cohen EA, Schluter M, et al. The Canadian study of the sirolimus-eluting stent in the treatment of patients with long de novo lesions in small native coronary arteries (C-SIRIUS). J Am Coll Cardiol 2004;43:1110-5.

88. Schofer J, Schluter M, Gershlick AH, et al. Sirolimus-eluting stents for treatment of patients with long atherosclerotic lesions in small coronary arteries: double-blind, randomised controlled trial (E-SIRIUS). Lancet 2003;362:1093-9.

89. Lemos PA, Lee CH, Degertekin M, et al. Early outcome after sirolimus-eluting stent implantation in patients with acute coronary syndromes: insights from the Rapamycin-Eluting Stent Evaluated At Rotterdam Cardiology Hospital (RESEARCH) registry. J Am Coll Cardiol 2003;41:2093-9.

90. Lemos PA, Saia F, Hofma SH, et al. Short- and long-term clinical benefit of sirolimus-eluting stents compared to conventional bare stents for patients with acute myocardial infarction. J Am Coll Cardiol 2004;43:704-8.

91. Lemos PA, Serruys PW, van Domburg RT, et al. Unrestricted utilization of sirolimus-eluting stents compared with conventional bare stent implantation in the 'real world': the Rapamycin-Eluting Stent Evaluated At Rotterdam Cardiology Hospital (RESEARCH) registry. Circulation 2004;109:190-5.

92. Hoye A, Tanabe K, Lemos PA, et al. Significant reduction in restenosis after the use of sirolimus-eluting stents in the treatment of chronic total occlusions. J Am Coll Cardiol 2004;43:1954-8.

93. Liistro F, Stankovic G, Di MC, et al. First clinical experience with a paclitaxel derivate-eluting polymer stent system implantation for in-stent restenosis: immediate and long-term clinical and angiographic outcome. Circulation 2002;105:1883-6.

94. Park SJ, Shim WH, Ho DS, et al. A paclitaxel-eluting stent for the prevention of coronary restenosis. N Engl J Med 2003;348:1537-45.

95. Grube E, Silber S, Hauptmann KE, et al. TAXUS I: six- and twelve-month results from a randomized, double-blind trial on a slowrelease paclitaxel-eluting stent for de novo coronary lesions. Circulation 2003; $107: 38-42$.

96. Colombo A, Orlic D, Stankovic G, et al. Preliminary observations regarding angiographic pattern of restenosis after rapamycin-eluting stent implantation. Circulation 2003;107:2178-80.

97. Tanabe K, Serruys PW, Grube E, et al. TAXUS III trial: in-stent restenosis treated with stent-based delivery of paclitaxel incorporated in a slow-release polymer formulation. Circulation 2003;107:559-64.
98. Kastrati A, Mehilli J, von BN, et al. Sirolimus-eluting stent or paclitaxeleluting stent vs balloon angioplasty for prevention of recurrences in patients with coronary in-stent restenosis: a randomized controlled trial. JAMA 2005;293:165-71.

99. Sousa JE, Costa MA, Abizaid A, et al. Sirolimus-eluting stent for the treatment of in-stent restenosis: a quantitative coronary angiography and threedimensional intravascular ultrasound study. Circulation 2003;107:24-7.

100. Degertekin M, Regar E, Tanabe K, et al. Sirolimus-eluting stent for treatment of complex in-stent restenosis: the first clinical experience. J Am Coll Cardiol 2003;41:184-9.

101. Neumann FJ, Desmet W, Grube E, et al. Effectiveness and safety of sirolimus-eluting stents in the treatment of restenosis after coronary stent placement. Circulation 2005;111:2107-11.

102. Teirstein PS, Massullo V, Jani S, et al. Catheter-based radiotherapy to inhibit restenosis after coronary stenting. N Engl J Med 1997;336:1697-703.

103. Raizner AE, Oesterle SN, Waksman R, et al. Inhibition of restenosis with beta-emitting radiotherapy: Report of the Proliferation Reduction with Vascular Energy Trial (PREVENT). Circulation 2000;102:951-8.

104. Waksman R, White RL, Chan RC, et al. Intracoronary gamma-radiation therapy after angioplasty inhibits recurrence in patients with in-stent restenosis. Circulation 2000;101:2165-71.

105. Leon MB, Teirstein PS, Moses JW, et al. Localized intracoronary gamma-radiation therapy to inhibit the recurrence of restenosis after stenting. N Engl J Med 2001;344:250-6.

106. Waksman R, Raizner AE, Yeung AC, Lansky AJ, Vandertie L. Use of localised intracoronary beta radiation in treatment of in-stent restenosis: the INHIBIT randomised controlled trial. Lancet 2002;359:551-7.

107. Popma JJ, Suntharalingam M, Lansky AJ, et al. Randomized trial of 90Sr/90Y beta-radiation versus placebo control for treatment of in-stent restenosis. Circulation 2002;106:1090-6.

108. Waksman R, Ajani AE, White RL, et al. Intravascular gamma radiation for in-stent restenosis in saphenous-vein bypass grafts. N Engl J Med 2002;346:1194-9.

109. Waksman R, Cheneau $\mathrm{E}$, Ajani AE, et al. Intracoronary radiation therapy improves the clinical and angiographic outcomes of diffuse in-stent restenotic lesions: results of the Washington Radiation for In-Stent Restenosis Trial for Long Lesions (Long WRIST) Studies. Circulation 2003;107:1744-9. 